\title{
Exploring the global animal biodiversity in the search for new drugs - Spiders, scorpions, horseshoe crabs, sea spiders, centipedes, and millipedes
}

\author{
Dennis RA Mans* \\ Department of Pharmacology, Faculty of Medical Sciences, Anton de Kom University of Suriname, Paramaribo, Suriname
}

\begin{abstract}
Drug discovery and development programs have historically mainly focused on plants with medicinal properties and the extensive knowledge of traditional healers about these plants. More recently, the vast array of marine invertebrates and insects throughout the world have been recognized as additional sources for identifying unusual lead compounds to obtain structurally novel and mechanistically unique therapeutics. The results from these efforts are encouraging and have yielded a number of clinically useful drugs. However, many arthropods other than insects - such as spiders, scorpions, horseshoe crabs, sea spiders, centipedes, and millipedes - also produce hundreds of bioactive substances in their venom that may become useful in the clinic. Many of these chemicals are defensive and predatory weapons of these creatures and have been refined during millions of years of evolution to rapidly and with high specificity and high affinity shut down critical molecular targets in prey and predators. Exploration of these compounds may lead to the development of, among others, novel drugs for treating diseases caused by abnormalities in humans in the same (evolutionary conserved) molecular targets such as erectyle dysfunction, botulism, and autoimmune disorders, as well as the identification of novel antineoplastic, antimicrobial, and antiparasitic compounds. This paper addresses the importance of bioactive compounds from spiders, scorpions, horseshoe crabs, sea spiders, centipedes, and millipedes to these advances.
\end{abstract}

\section{Introduction}

Medicinal plants have yielded a multitude of modern, allopathic drugs that are essential for our health and well-being [1,2]. A few examples are the analgesic salicylic acid from the white willow Salix alba L. (Salicaceae) [3]; the chemotherapeutic agent paclitaxel from the American yew Taxus brevifolia Nutt. (Taxaceae) [4]; the antiparkinson medication apomorphine, a semisynthetic compound derived from morphine from the opium poppy Papaver somniferum L. (Papaveraceae) [5]; the bronchodilator tiotropium, a derivative of atropine from the deadly nightshade Atropa belladonna L. (Solanaceae) [6]; the artemisinin-derived antimalarials from the Chinese sweet wormwood Artemisia annua L. (Asteraceae) [7]; and the anti-alzheimer drug galantamine that was first isolated from the Caucasian snowdrop Galanthus caucasicus (Baker) Grossh. (Amaryllidaceae) [8].

Other sources of therapeutics are certain minerals, microorganisms, and vertebrates. For instance, medicinal iron can be given in cases of iron-deficiency anemia [9], pastes with zinc oxide powder to individuals with atopic eczema [10], and injectable gold salts to patients with rheumatoid arthritis [11]. Fungi from the genus Penicillium (Trichocomaceae) yielded the $\beta$-lactam antibiotics [12], and strains of the bacteria Streptomyces griseus (Streptomycetaceae) [13] and Micromonospora purpurea (Foulerton 1905) Ørskov 1923 (Micromonosporaceae) [14] produced the aminoglycoside antibiotics streptomycin and gentamicin, respectively. And marine fish in the family Gadidae provide cod liver oil that protects against rickets and other vitamin deficiencies [15], the venom of the South American lancehead viper Bothrops jararaca Wied-Neuwied, 1824 (Viperidae) led to the angiotensin-converting enzyme-inhibiting antihypertensive captopril [16], and Premarin ${ }^{\circ}$, a mixture of estrogens isolated from pregnant mares' urine proved beneficial in menopausal symptoms [17].
More recently, drug discovery and development programs have directed their attention to other unusual sources such as marine invertebrates in the hope of identifying more efficacious therapeutics with novel chemical structures and unique mechanisms of action. Examples that emerged from these efforts are the promising anti-cancer dolastatins isolated from the marine sea hare Dolabella auricularia, Lightfoot, 1786 (Aplysiidae) [18]; girolline from the New Caledonian sponge Pseudaxinyssa cantharella Lévi, 1983 (Halichondriidae) that may represent a lead compound for new drugs to fight malaria [19]; and the powerful analgesic ziconitide molded on the basis of the extremely potent conotoxins produced by predatory cone snails from the genus Conus (Conidae) [20].

Similarly, systemic exploration of the vast array of existing insect species may help identify entirely new therapeutics. These efforts may lead to the development of, among others, a number of anticancer and/ or antimicrobial agents derived from cantharidin from blister beetles of the genera Mylabris and Lytta (Meloidae) [21], mastoparans from vespid wasps (Vespidae) and several species of hornets in the genera Vespa and Provespa (Vespidae) [22], as well as melittin and lasioglossins from bee species such as Apis mellifera Linnaeus, 1758 (Apidae) and Lasioglossum laticeps Schenck, 1870 (Halictidae) [23].

Correspondence to: Dennis RA Mans, PhD, Department of Pharmacology, Faculty of Medical Sciences, Anton de Kom University, Kernkampweg 5, Paramaribo, Suriname, Tel/Fax: 597-441071; E-mail: dennismans16@gmail. com; dennis_mans@yahoo.com

Key words: spiders; scorpions; horseshoe crabs; sea spiders; centipedes; millipedes, bioactive compounds; novel therapeutics

Received: August 22, 2017; Accepted: September 18, 2017; Published: September 21, 2017 
A comprehensive overview of marine invertebrates as potential sources of new drugs is given in reference [24], while bioactive compounds from insects and their potential therapeutic applicability have recently been reviewed in reference [25]. The present paper addresses bioactive compounds with potential clinical applicability from arthropod subphyla other than the Insecta, namely those from the Chelicerata and Myriapoda. The Crustaceae have been left out from this overview because of the relative unimportance of their constituents to medicine and biotechnology, even though fairly recently a venomous crustacean, the cave-dwelling, blind, pigment-less, hermaphroditic Xibalbanus tulumensis Yager, 1987 (Remipedia, Nectiopoda: Speleonectidae) has been discovered [26,27].

\section{Background}

\section{Characteristics of Arthropoda}

The phylum Arthropoda is the only group of animals that has completely adapted to life in dry environments, besides the amniotes (reptiles, birds, and mammals). Their evolutionary ancestry dates back to the Cambrian period, 541 to 485.4 million years ago [28]. The total number of arthropod species has been estimated between $1,170,000$ and 5 to 10 million, accounting for over $80 \%$ of all known living animal species and comprising more than the total number of species in all other animal phyla combined, living and extinct [29]. Arthropods are found in virtually every marine, freshwater, terrestrial, and air ecosystem, and vary enormously in their habitats, life histories, dietary preferences, and size [29]. The red king crab Paralithodes camtschaticus Tilesius, 1815 (Malacostraca, Decapoda: Lithodidae), for instance, prefers the relatively low temperatures of the Alaskan waters and has a carapace width of twenty-eight centimeters and a leg span of 1.8 meters [30], while the members of crustacean subclass Copepoda (class Maxillopoda) are encountered in all marine and most freshwater habitats and are only one to two millimeters in length [31].

Despite the astonishing diversity of arthropod species, their basic body plan is fairly constant [32]. Firstly, all members of this phylum carry (paired) jointed appendages (Figure 1), a distinguishing characteristic captured in the ancient Greek words 'arthro' for 'joint and 'podos' for 'foot' to give the name 'Arthropoda'. The appendages may be either biramous (branched) or uniramous (unbranched). The larval stages in general lack jointed limbs and undergo total metamorphosis to become adult forms.

Other important characteristics shared by most arthropods are a bilaterally symmetric and strongly segmented body (Figure 1) covered by an exoskeleton made up of chitin and proteins that may be biomineralized with rock-hard calcium carbonate. As they grow, arthropods replace their exoskeleton periodically by moulting in a process called ecdysis. Some body segments are fused to form specialized and functional units called tagmata which usually include the three major sections, head, thorax, and abdomen (Figure 1). However, in most spiders and scorpions the head and the thorax are fused to a cephalothorax, while in harvestmen, ticks, and mites the three tagmata are even completely joined, giving the impression of one structure.

Many arthropods have complex mouthparts and highly developed sensory organs including statocysts, antennae, as well as sensitive hairs on the surface of the body which they use to detect touch signals, water currents, or chemicals. Most species have paired compound eyes and many also have a number of simpler eyes called ocelli. However, with the exception of spiders, they cannot form images but only detect the direction of light. Arthropods typically have an open circulatory system consisting of a tubular heart that pumps blood though arteries to the

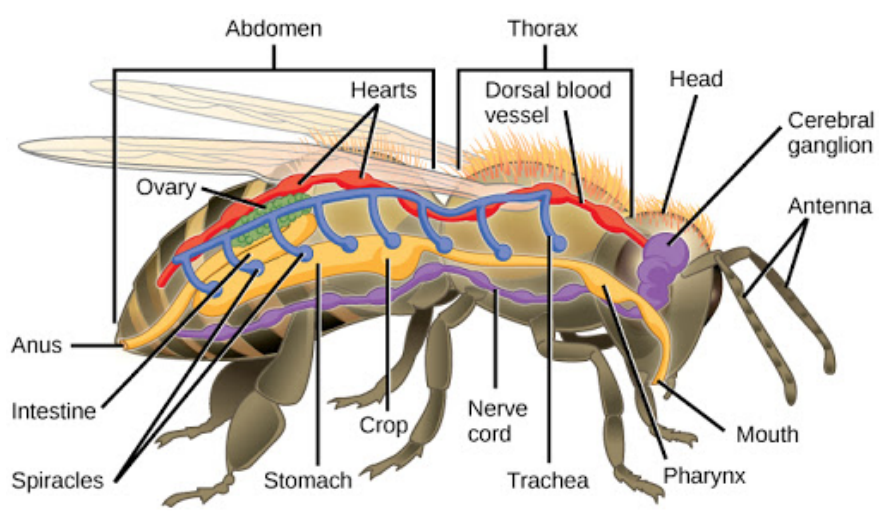

Figure 1. Basic body plan of arthropods. Note the segmented body and the jointed appendages (from: bio1520.biology.gatech.edu/biodiversity/animals-invertebrates/)

hemocoel, the major body cavity that accommodates the internal organs. The blood analogue is called the hemolymph and the blood pigment is the copper-containing hemocyanin. Gas exchange takes place through the body surface, and/or by means of gills, tracheae, or book lungs.

Arthropods have a complete gut with a mouth and an anus. Excretion takes place by means of projections of the digestive tract called malpighian tubules. The nervous system comprises chains of ganglia which serve various parts of the body and are connected to a brain consisting of fused cerebral ganglia that lies dorsally from the esophagus. In most species, the sexes are separate. Fertilization usually occurs internally, and most species are egg-laying. In some species the eggs hatch to give miniature versions of adults while others pass through an immature larval stage and undergo a dramatic metamorphosis before reaching adult form.

\section{Classification of Arthropoda}

The Arthropoda are classified into five subphyla, namely the extant Chelicerata, Myriapoda, Crustacea, and Hexapoda, as well as the extinct Trilobitomorpha (Schema 1) [33,34]. The chelicerates comprise, among others, spiders, scorpions, horseshoe crabs, as well as ticks and mites. This group is characterized by the presence of chelicerae, appendages just above or in front of the mouth. The chelicerae of scorpions and horseshoe crabs are tiny claws that are used for feeding, but those of spiders have developed to fangs for injecting venom. Myriapods comprise centipedes, millipedes, and their relatives, and have many body segments, each characteristically bearing one or two pairs of legs. Crustaceans are primarily aquatic (with the exception of woodlice) and are characterized by having biramous appendages. They include, among others, lobsters, crabs, barnacles, crayfish, and shrimp. The Hexapoda constitute the largest number of arthropod species and include the insects as well as three small orders of insect-like animals. Hexapods are named for their most distinctive feature, the presence of three pairs of legs attached to the thorax, which contrasts with the greater number of legs in most other arthropods. The trilobites probably were the earliest groups of arthropods, first appearing in the Early Cambrian period some 521 million years ago and dominating the oceans for the next 260 to 270 million years, but disappeared completely in the Permian-Triassic extinction about 252 million years ago.

\section{Defenses of Arthropoda}

As mentioned above, arthropods probably date back more than 500 million years ago $[28,32]$ and have become today the most numerous group of animal species on Earth [29]. Their evolutionary success is 


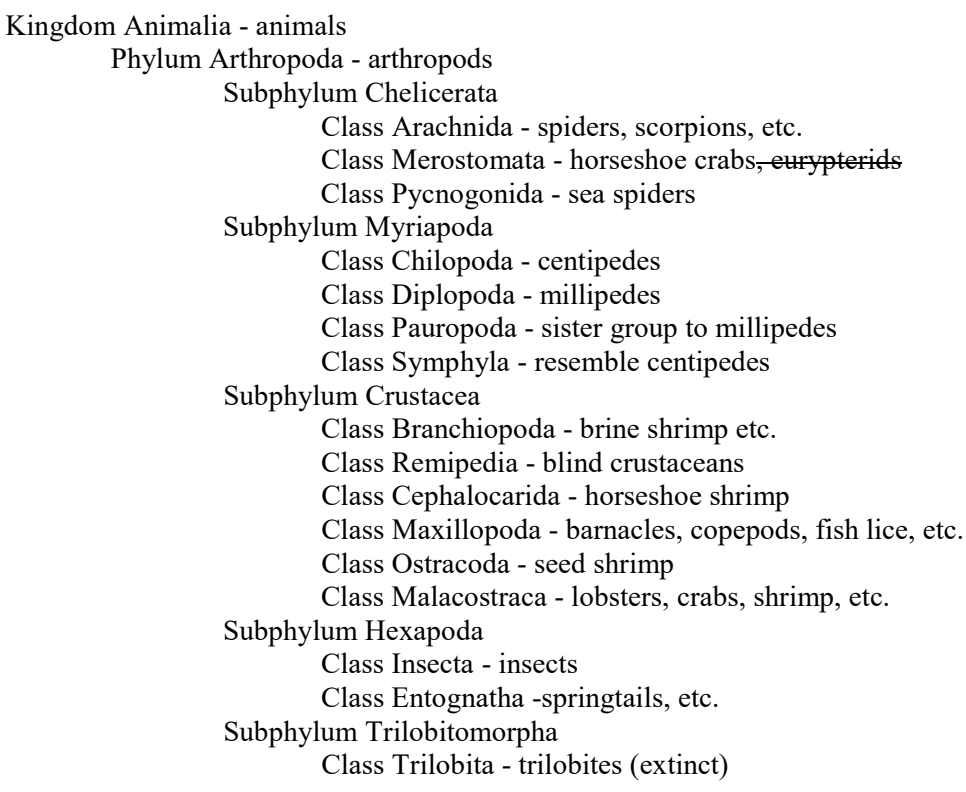

Schema 1. Taxonomic position of the insects in the animal kingdom

for an important attributable to their segmented appendages and body which offer flexibility, and their exoskeleton which gives their body its shape, color, and texture; protects and supports the muscles and internal organs; helps the body to retain moisture; and represents their first-line defense against predators. Many arthropods have developed additional - and sometimes very original - means of improving their chances for survival. For instance, hermit crabs - crustaceans in the order Decapoda (class Malacostraca) - protect themselves by carrying an abandoned snail shell on their back in which they retreat when threatened (Figure 2) [35]. Decorator crabs (Malacostraca, Decapoda: Majoidea) hide from or ward off predators by attaching camouflaging debris and/or noxious sedentary animals and/or plants to their exoskeleton [36]. And various arthropods cast off a limb when under threat - a behavior called autotomy - thus distracting the attacker and creating an opportunity to escape; once in safety, the lost body part is regenerated [37].

However, many arthropods do not passively await their fate counting on their wits or good luck, but actively protect themselves from predation and attack by discharging an astounding array of highly effective defensive toxins on their assailant [38]. Well-known examples are the noxious monoterpene hydrocarbons from certain termites (Insecta, Blattodea: Nasutitermitinae) [39]; the sticky corrosive and irritant substance from the exploding body of the Malaysian carpenter ant (Insecta, Hymenoptera: Formicidae) [40]; the boiling hot, toxic, and foul-smelling quinonoids from bombardier beetles (Insecta, Coleoptera: Carabidae) [41]; and the foul-smelling and foul-tasting foamy mixture of phenols, terpenes, and benzoquinones from the North American eastern lubber grasshopper (Insecta, Orthoptera: Romaleidae) [42].

Members of the arthropod subphyla chelicerates and myriapods have also developed sophisticated chemical artillery that is mobilized when under attack. Harvestmen of the genus Goniosoma (Arachnida, Opiliones: Gonyleptidae) secrete volatile alarm substances as well as alkylated 1,4-benzoquinones from exocrine glands on their cephalothorax when confronted with impending danger $[43,44]$.

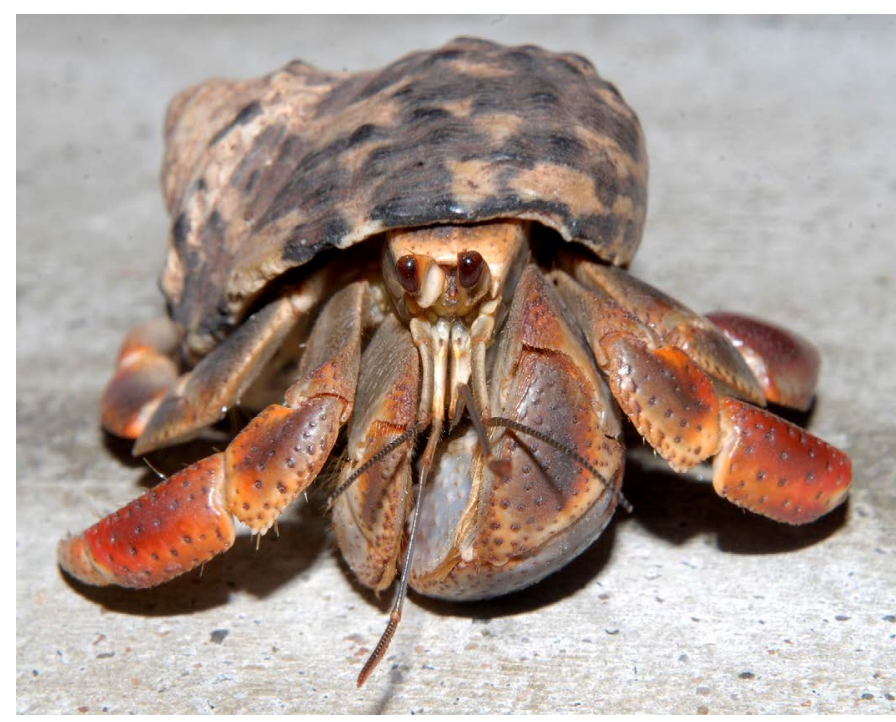

Figure 2. A hermit crab protecting its vulnerable abdomen with an abandoned snail shell (from: https://goo.gl/images/YeJtEV)

The batik golden web spider Nephila antipodiana Walckenaer, 1841 (Arachnida, Araneae: Araneidae) in the tropical forests of South-east Asia incorporates 2-pyrrolidinone in the silk it uses to spin its web in order to ward off predatory ants, moths, and caterpillars [45].

Furthermore, when threatened, certain species of tarantula (Arachnida, Araneae: Theraphosidae) brush off the urticating hairs on their body with rapid leg-flicking motions, launching the hairs on attackers and predators, causing intense irritation [46]. The bristly millipede Polyxenus fasciculatus Say, 1821 (Diplopoda, Polyxenida: Polyxenidae) does not have chemicals for its defense as most millipedes, but instead also sheds detachable and irritating hairs from a pair of bristle tufts at its rear on intruding predatory ants, entangling and deactivating the ants [47]. Notably, the South African spitting scorpion Parabuthus transvaalicus Purcell, 1899 (Buthidae) can both sting and 
forcefully spray its neurotoxic venom on attackers [48]. Many juliform millipedes (superorder Juliformia) passively ooze chemicals from their repugnatorial glands on intruders, but some larger species in the orders Spirobolida and Spirostreptida can also eject their secretions on assailants from distances as far as fifty centimeters away [49].

Other myriads such as the members of the large and widespread order of the flat-backed polydesmid millipedes (Diplopoda, Polydesmida: Polydesmidae) protect themselves from predation by secreting a defensive substance from ozopores running along the length of their body that contains cyanogenetic compounds such as benzoyl cyanide [50,51]. And threatened pill millipedes in the superorder Oniscomorpha roll into a protective coil to shield their vulnerable ventral surface (a behavior called volvation or conglobation) [52] and exude noxious, caustic, and toxic liquids from glands along the length of their body on the predator [53].

As some of the defensive substances of these creatures have meaningful pharmacological properties, they may serve as lead compounds for developing novel diagnostic compounds and therapeutic drugs.

\section{Chelicerata}

The Chelicerata encompass over 77,000 described living species (perhaps even about 500,000) and are one of the most diverse groups of animals on our planet $[54,55]$. The chelicerate body consists of two tagmata, the cephalothorax originating from six segments, and the abdomen made up of thirteen segments. A distinguishing characteristic of this arthropod subfamily is the presence of pincer-like appendages called chelicerae developed from their most anterior appendages [54,55]. A a result, their name 'Chelicerata' is derived from the ancient Greek words 'khēlè for 'claw' and 'kéras' for 'horn'. In most subgroups, the chelicerae are rather modest and used to manipulate food, but in spiders they form fangs for injecting venom into prey [54,55]. Apart from the chelicerae, there are five pairs of unbranched appendages, viz. a pair of pedipals (the second pair of appendages that has been modified for sensory functions or for manipulating prey) and four pairs of walking legs [54,55]. Chelicerates have neither mandibles nor antennae $[54,55]$.

Chelicerates were originally predators but have diversified to use all major feeding strategies including predation, parasitism, herbivory, scavenging, and eating decaying organic matter [54,55]. Most carnivorous species produce powerful digestive enzymes which are injected into the prey to dissolve it, after which it is ingested [54,55].

The Chelicerata can be distinguished into four classes, the extant Arachnida (spiders, scorpions, mites, ticks, etc.), Xiphosura (horseshoe crabs), and Pycnogonida (sea spiders), as well as the extinct Eurypterida (sea scorpions) [54,55]. The Arachnida (from the ancient Greek word 'arákhne' for 'spider') includes over 100,000 described species which are in general found in terrestrial and fairly warm, dry habitats $[54,55]$. They are grouped into four orders, the Opiliones (harvestmen or daddy longlegs), the Acari (ticks and mites), the Araneae ('true' spiders), and the Scorpiones (scorpions).

The approximately 5,000 species of harvestmen are spider-like arachnids with a compact rounded body and extremely long, slender legs which they regularly lose in accidents and brushes with competitors and predators such as mites, aphids, and caterpillars [56]. They hunt and defend themselves by secreting a variety of defensive compounds including quinones, ketones, and phenols from their exocrine glands
[57]. Ticks and mites encompass about 30,000 different species and are the largest and most diverse group of arachnids [58]. Most are very tiny (less than one millimeter long) and some are ectoparasites which embed themselves in the skin of vertebrate animals and feed on blood [58]. Certain ticks carry and spread bacteria of the genera Borrelia (Spirochaetaceae) and Rickettsia (Rickettsiaceae) which cause Lyme disease [59] and Rocky Mountain spotted fever [60], respectively.

When compared to the defensive chemicals of harvestmen, ticks, and mites, those of spiders and scorpions have more relevance to biotechnological and therapeutic applications. For this reason, some of the bioactive compounds in the venoms of the latter creatures are in detail addressed hereunder. Spider and scorpion venoms consist of hundreds of different compounds which have evolved over millions of years to produce a cocktail of amazingly diverse compounds with numerous pharmacological effects. The medicinally most important components are the neuro- and cardiotoxins which often exert their effects by modulating ion channels, integral plasma membrane proteins that allow the selective passage of charged ions from one side of cellular membranes to the other [61,62]. Important ion channels are those for potassium, sodium, chloride, and calcium [61,62] which are involved in, among others, the generation of nerve impulses and nerve conduction across synapses, as well as a wide variety of biological processes such as cardiac, skeletal, and smooth muscle contraction, epithelial transport of nutrients and ions, and T-cell activation [61,62].

The critical importance of ion channels is reflected by the serious disorders that result from genetic and autoimmune disorders that affect their functioning. A few examples of these so-called channelopathies are epilepsy, fibromyalgia, cystic fibrosis, episodic ataxia, and arrhythmias [63]. Thus, it is understandable that disruption of normal channel function by spider or scorpion envenomation affects various vital systems including nervous, cardiovascular, gastrointestinal, and respiratory system, rapidly resulting in incapacitation of prey or attacker. At the same time, however, detailed insight into these processes is leading to the identification and optimization of novel compounds that selectively and specifically pursue the intended therapeutic targets $[64,65]$.

\section{Bioactive compounds from Araneae}

With at least 45,700 different species in 113 families, the order Araneae (Latin for 'spider') is the largest of the arachnids and ranks seventh among all other orders of organisms with respect to total species diversity [66]. Their body consists of a cephalothorax and an abdomen which are covered by a cuticle made of chitin and proteins. The cephalothorax houses a primitive brain that is in fact a fusion of their anterior ganglia [66]. The cephalothorax is connected to the abdomen by a small, cylindrical pedicel which enables the abdomen to move independently when producing silk [66]. The abdomen is made up of only five segments which are in general joined together with no external trace of segmentation. The posterior part characteristically bears specially modified appendages called spinnerets for producing silk [66]. There are five other pairs of appendages which include three pairs of walking legs, one pair of pedipalps, and one pair of chelicerae [66]. The chelicerae consist of two sections and terminate in fangs for injecting venom and are fold away behind the upper sections when not in use [66]. Spiders have no extensor muscles in their limbs and instead extend them by hydraulic pressure [66].

Spiders occur in a large range of sizes, one of the smallest being Patu digua Forster \& Platnick, 1977 (Symphytognathidae) from Colombia which has a body length of only about 0.37 millimeters [67], and the 
largest and heaviest occurring among tarantulas (Theraphosidae) with body lengths of up to nine centimeters and leg spans of up to twenty-five centimeters [68]. Notwithstanding, with the exception of the herbivorous Central American jumping spider Bagheera kiplingi Peckham \& Peckham, 1896 (Salticidae) [69], all species are predators, mostly hunting on insects and other spiders, but a few large species also consume small birds and lizards [66]. For this purpose, many produce poisons to immobilize their prey, perhaps the most famous one being the female black widows in the genus Latrodectus Walckenaer, 1805 (Theridiidae) [70].

Spiders use their poisons also for self-defense which may cause occasional accidents in humans [66]. However despite their fearsome reputation, according to the World Health Organization, only four spider genera are harmful to humans, namely Loxosceles, Phoneutria, Latrodectus, and Atrax [38]. The venom of these groups consists of complex mixtures of proteic toxins or peptides and has several biological activities which act by different pharmacological mechanisms and have extensively been investigated in the search for new drugs and biotechnological products [71].

Treatments for erectile dysfunction: Brazilian wandering spiders or armed spiders are grouped in the genus Phoneutria Perty, 1833 (Ctenidae) and occur in South and Central America [72]. They are among the largest spiders and are very aggressive, sometimes attacking without apparent provocation and leaping up to twenty centimeters on the victim [72]. Assuming a characteristic 'attack' posture with frontal legs held before biting, they are also called 'armadeiras' in Brazil [72]. Indeed, meaning 'murderess' in ancient Greek, the genus name certainly seems well chosen. One of the most important species is $P$. nigriventer Keyserling, 1891 (Figure 3) which is responsible for a substantial number of injuries due to spider bites in Brazil [72].

The bite of a wandering spider initially causes severe burning pain at the site of the bite as well as sweating and goose bumps, which are rapidly followed by systemic symptoms including hypertension and arrhythmias, pulmonary edema, nausea and vomiting, priapism, hypothermia, convulsions, and sometines even death [73]. These symptoms are for an important part attributable to the neurotoxic substances in the venom [74]. These cause, among others, excitation of serotonin 5-HT4 receptors of sensory nerves that not only causes intense pain but also the release of peptides such as substance $P$ which triggers inflammation; activation of a potent neurotoxin that has broadspectrum calcium channel-blocking properties, inhibiting glutamate

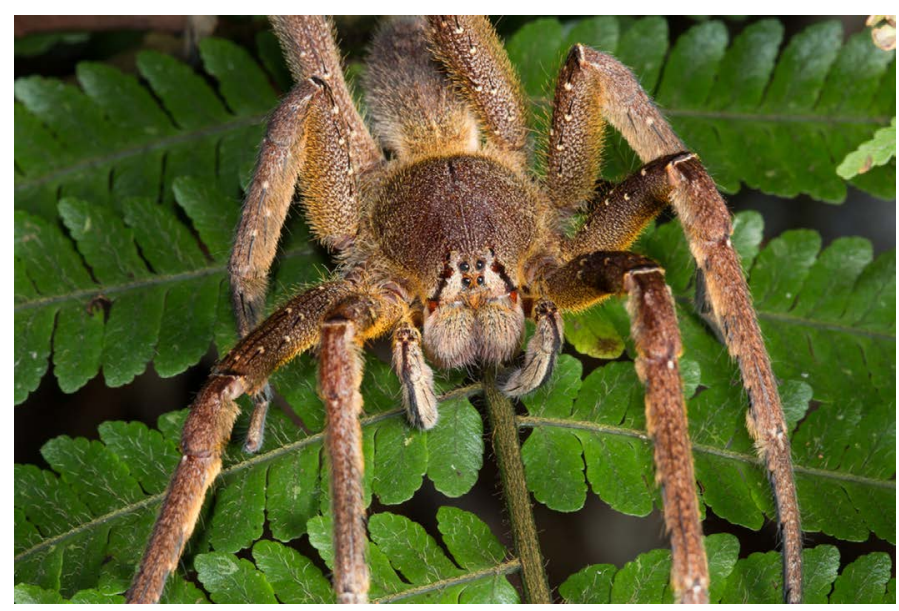

Figure 3. The Brazilian wandering spider Phoneutria nigriventer Keyserling, 1891 (Arachnida, Araneae: Ctenidae) (from: https://goo.gl/images/S7Bzsx) release, calcium uptake, and glutamate uptake in neural synapses; and stimulation of the formation of nitric oxide that dilates blood vessels and increases blood flow [74].

Based on the latter observation and the occurrence of priapism following P. nigriventer envenomation [74], the potential of certain ingredients in the venom for treating erectile dysfunction is under investigation [75]. So far, two such substances have been identified, namely the peptides PnTx2-5 and PnTx2-6 (Pn from P. nigriventer which are also referred to as Tx2-6 and Tx2-5, respectively [76-78]. These compounds delayed the fast inactivation of voltage-dependent sodium channels [79] resulting in a persistent sodium current that caused depolarization block, and stimulated the activity of nitric oxide synthase and the release of nitric oxide, enhancing cGMP levels and promoting vasodilation and increasing blood flow [76,80,81].

PnTx2-5 and PnTx2-6 acted on cavernosal tissue preparation in vitro [76,77], in laboratory mice [82], as well as in animal models of hypertension [77,83], type-1 diabetes mellitus [80], and ageing [81]. Importantly, these compounds seemed to preferentially aim at testicles and penis [76] but at a site different from that targeted by sildenafil (Viagra) [81]. Notably, intraperitoneal injection of PnTx2-6 induced priapism in laboratory mice at doses that avoided most of the systemic toxic symptoms [84], and attempts to synthesize analogues with retained erectogenic effect but minimal side effects gave promising results $[78,85]$. Still, further studies are necessary to evaluate the safety of these compounds as drugs for human use.

Antitoxins for botulism: Black widow spiders (genus Latrodectus Walckenaer, 1805, family Theridiidae) are a group of more than thirty species of spiders that are encountered in all parts of the world, including China, Central Asia, Southern Europe, North and South America, India, and Australia [86]. Latrodectus spp. have a characteristic hourglass design on their ventral abdomen and the females are infamous for practicing sexual cannibalism, a macabre behavior in which they would kill and eat the male after mating [87]. However, although this behavior is not uncommon in certain species of brown widows [87], female widow spiders of most species rarely kill their mates [87].

These spiders are highly venomous [86] and are responsible for a substantial number of envenomations around the world [88]. Unlike other venomous animals, Latrodectus spp. have toxins not only in their venom glands, but also throughout their body, and even in their eggs and newborn spiderlings [89]. This is presumably a protective mechanism for increasing the probability of individual survival and species continuation. The venom causes neurotoxic symptoms such as myalgias, paresthesias, muscle contractures, drooling, nausea, vomiting, arterial hypotension, shock, and in some cases even death [90]. This set of symptoms is called latrodectism [90] and has been associated with the actions of neurotoxic venom components on presynaptic nerves which trigger a massive release of neurotransmitters, particularly norepinephrine and acetylcholine [91].

Initial studies with the venom of the Mediterranean black widow L. tredecimguttatus Rossi, 1790 (Theridiidae) (Figure 4) have indicated that the symptoms of the venom are mainly attributable to at least seven large acidic proteins ( $\mathrm{pI} \sim 5.0-6.0$; MW 110 - $140 \mathrm{kDa}$ ) called latrotoxins $[92,93]$. As most of these compounds are targeted against insects, they are also referred to as latroinsectotoxins $(\alpha, \beta, \gamma, \delta$, and $\varepsilon$-LIT) [94]. $\alpha$-Latrotoxin is the only known venom component that aims specifically at vertebrates [92]. These compounds are responsible for the above-mentioned massive release of neurotransmitters from 


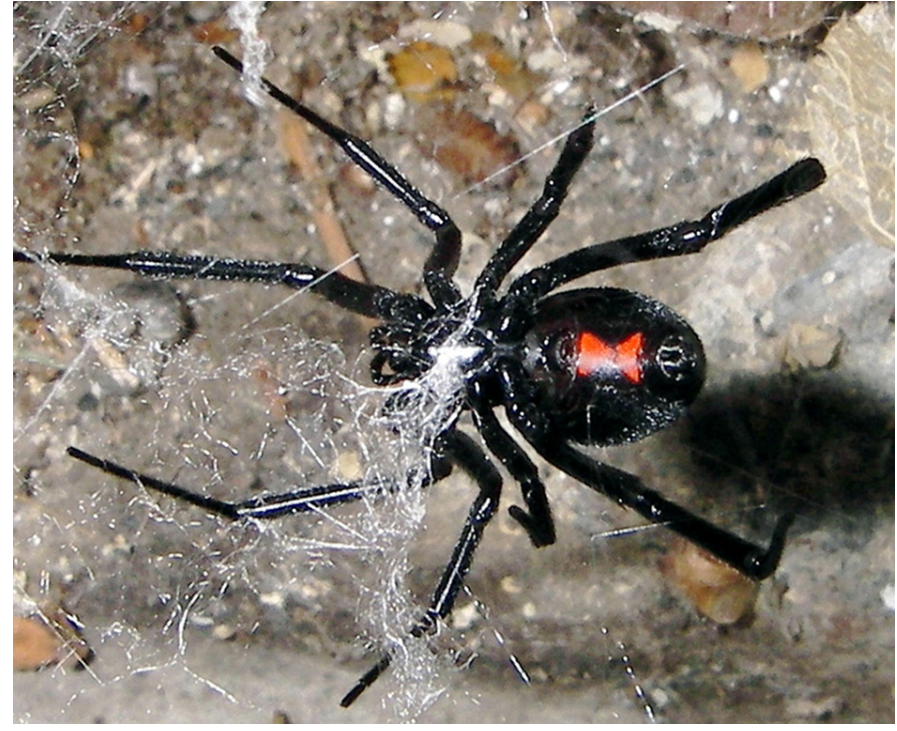

Figure 4. The black widow spider Latrodectus tredecimguttatus Rossi, 1790 (Arachnida, Araneae: Theridiidae) (from: https://goo.gl/images/e3mR8h)

the nerve terminals following envenomation by black widow spiders [95]. This mainly occurs through the formation of $\mathrm{Ca}^{2+}$-permeable channels in the lipid bilayers of presynaptic membranes following insertion of $\alpha$-LTX into the membranes and the subsequent influx of $\mathrm{Ca}^{2+}$ ions $[95,96]$.

Latrotoxins, particularly a-latrotoxin, have extensively been employed as tools to investigate the molecular mechanisms involved in the regulation of neurotransmitter release [95]. The special properties of a-latrotoxin may also be taken advantage of in cases of poisoning by botulinum toxin. This neurotoxin is among the most acutely deadly poisons known on Earth, causing neuromuscular paralysis by preventing acetylcholine release from axon endings at the neuromuscular junction [97], i.e., the exact opposite of a-latrotoxin. Indeed, using embryonic stem cell-derived neurons, the potential of $\alpha$-latrotoxin to antagonize the severity or duration of botulinum toxin-induced paralysis was demonstrated [98]. These advances are important when considering that botulinum toxin may be used as a biological weapon and is classified as a category A agent on the list of the US Centers for Disease Control and Prevention in Atlanta (GA) of major bioterrorism threats [99].

\section{Bioactive compounds from Arachnida, Scorpiones}

The Scorpiones (the romanization of the Greek word 'skorpios') comprise about 2,000 different species of predatory arachnids grouped in thirteen extant families [100]. They are characterized by the pair of pedipalps modified as grasping claws and the long, segmented tail often carried in a characteristic forward curve over the back with a venomous stinger at the end [101]. Scorpions can be found in virtually every terrestrial habitat on all continents except Antarctica, in general in dry, hot environments, although some species are also encountered in forests and wet savannas [100]. All species are nocturnal, hiding during the day in their burrows in the soil or under rocks, logs or debris [100].

The body of a scorpion is divided into a cephalothorax and an abdomen which is subdivided into a broad anterior mesosoma and a narrow metasoma [101]. The cephalothorax comprises the thick and hard carapace; two to five pairs of eyes; chelicerae pedipalps modified as grasping claws for catching prey, defense, and sensory purposes; and four pairs of walking legs [101]. The mesosoma is made up of the anterior seven segments of the abdomen and is protected by hardened dorsal and ventral plates [101]. The long metasoma or 'tail' consists of five segments, the fifth of which bears the venomous stinger for injecting venom from a pair of venom glands [101].

Scorpions are prey for birds, centipedes, lizards, mice, opossums, and rats, and mainly hunt on small arthropods [102]. They detect their victims with highly sensitive tactile hairs on their pincers and use their pincers to catch the prey which they then either crush with their claws or immobilize with their neurotoxic venom $[102,103]$. The venom is fast-acting and is also used as a defense against predators [102,103], perturbing the normal functioning of nerve, muscle, and heart cells by altering ion channels [102,103]. The most potent venom components are long-chain polypeptide neurotoxins which cause stabilization of voltage-dependent sodium channels in the open position, leading to continuous, prolonged repetitive firing of somatic, sympathetic and parasympathetic neurons, and short polypeptide neurotoxins which block potassium channels $[102,103]$.

Only about twenty-five species of scorpion have venom that is deadly to humans $[102,103]$. Most of these belong to the large family Buthidae, particularly in the genera Buthus (Mediterranean Spain to the Middle East), Parabuthus (western and southern Africa), Hottentotta (South Africa to south-east Asia), Tityus (Central America, South America, and the Caribbean), Leiurus (northern Africa and the Middle East), Androctonus (northern Africa to south-east Asia), Centruroides (southern USA, Mexico, Central America, and the Caribbean), and Mesobuthus (through out the Asia) [102]. Scorpion envenomation with high morbidity and mortality is usually due to either excessive autonomic activity and cardiovascular toxic effects or neuromuscular toxic effects [103]. Similarly to those of spider venoms, these effects are mainly attributable to peptides that specifically target certain ion channels and cell membrane components.

Diagnoses and therapy of gliomas: Chlorotoxin is a neurotoxin of thirty-six amino acids that was isolated in 1993 from the venom of the deathstalker scorpion Leiurus quinquestriatus Hemprich \& Ehrenberg, 1829 (Buthidae) (Figure 5) [104]. The sting from this scorpion is not lethal to healthy human adults, but it is very painful and may cause agitation, an increased heartbeat, a raised blood pressure, an increased respiratory rate, and even convulsions and coma, particularly in children [105]. These symptoms are most likely not attributable to chlorotoxin, since this compound alone did not cause apparent signs of toxicity when injected in vertebrates [104].

Chlorotoxin exhibits two highly interesting properties. Firstly, it potently blocked chlorine channels in rat colonic epithelial cells

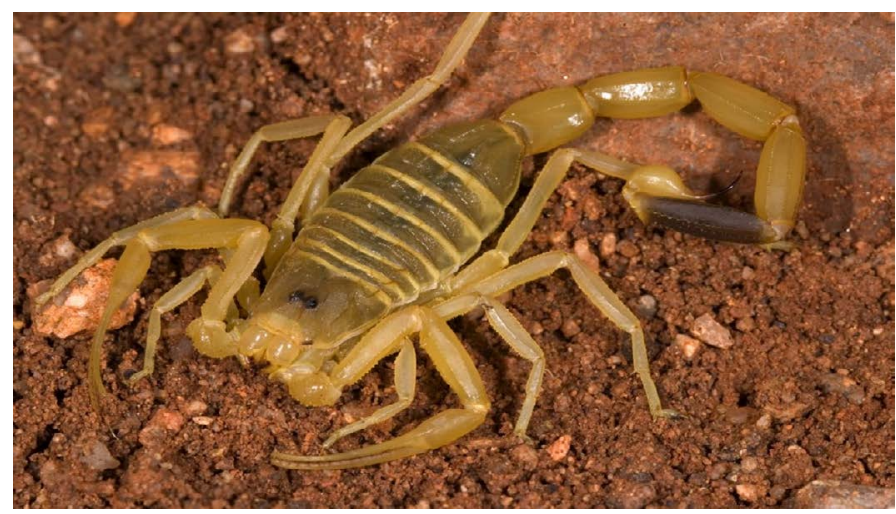

Figure 5. The deathstalker scorpion Leiurus quinquestriatus Hemprich \& Ehrenberg, 1829 (Arachnida, Scorpiones: Buthidae) (from: https://goo.gl/images/vHR5Ff) 
$[104,106]$ as well as in a various malignant glioma cell lines [107] and glioma cells from patient biopsies [108]. Secondly, radioactively labeled chlorotoxin could be used for detecting glioma cells in culture, human glioma xenografts in SCID mice, and glioma cells in patient biopsies [107]. In the latter case, the intensity of labeling increased with increasing malignancy grade of the tumors [107]. Notably, a fluorescently-tagged Cy5.5-chlorotoxin preferentially accumulated in foci from malignant glioma, medulloblastomas and other malignancies in transgenic mice that spontaneously develop these brain cancers [109]. Moreover, chlorotoxin bound to stained frozen and paraffin tissue sections of human biopsy tissues glioma cells as well as to other tumors of neuroectodermal origin [110], and deeply penetrated into tumors in a genetically engineered mouse model [109] and in adults with recurrent high-grade glioma [111].

These observations strongly suggested that chlorotoxin has a high degree of specificity for gliomas and that this property might be mediated by its ability to block chlorine channels. Indeed, chlorotoxin's affinity to gliomas may be attributed to the overexpression of chlorotoxin-sensitive chlorine channels in these tumor types [112]. Importantly, expression levels of these channels are relatively low in healthy tissues and in tumors of non-glial origin but increase with increasing tumor grade in gliomas [113]. Obstructing these channels using chlorotoxin impedes the movement of $\mathrm{Cl}^{-}$ions across the plasma membrane $[142,115]$. This results in alterations in shape and volume of the (glioma) cells which would restrict their motility and hamper their capacity to invade surrounding healthy brain tissues [114,115].

Thus, blocking chlorine channels using chlorotoxin may represent a novel and attractive strategy to inhibit invasion of gliomas and metastasis of neuroectodermal tumors, as suggested before [112,114116]. Contributing to this effect is the inhibitory effect of chlorotoxin on the activity and availability of matrix metalloprotease 2 [116] that is expressed in gliomas and other tumors but absent in normal (brain) tissues and may facilitate glioma cell invasiveness by enzymatically degrading the extracellular matrix [117].

The dual mechanism of chlorotoxin to interfere with glioma cell invasion may represent a novel way to cope with these malignancies. Support for the feasibility of such an approach comes from the observation that chlorotoxin coupled to iron nanoparticles inhibited glioma cell invasion in vitro, deactivated membrane-bound metalloproteinase 2, produced receptor-mediated endocytosis, and inhibited cell volume changes [118]. The glioma specificity of chlorotoxin also opens the door for targeted diagnosing and imaging strategies for gliomas [119]. The possibilities include the use of chlorotoxin alone; chlorotoxin coupled to fluorescent molecules, tumor paint using the Cy5.5 dye, or nanoparticles; or chlorotoxin coupled to radioisotopes, existing antineoplastic agents, or reactive oxygen species [119]. Of note, the results from clinical studies with ${ }^{131}$ I-TM601 (an iodinated synthetic version of chlorotoxin) as a tumortargeting peptide in glioma patients were encouraging [120].

Remedies for autoimmune disorders: Maurotoxin is a thirtyfour-amino acid peptide toxin that was first isolated from the venom of the Israeli gold scorpion Scorpio maurus palmatus Ehrenberg, 1828 (Scorpionidae) (Figure 6) [122]. This species of scorpion is six to eight centimeters long and most subspecies have a yellow to red-brown color [123]. They are mainly encountered in deserts and dry forests in Africa and Asia where they dig deep burrows to live in [123]. They feed on small crustaceans, ants, and beetles which they kill with their powerful chelae rather than their venom [123]. The venom of $S$. m. palmatus consists of three main groups of polypeptides, namely neurotoxins - including

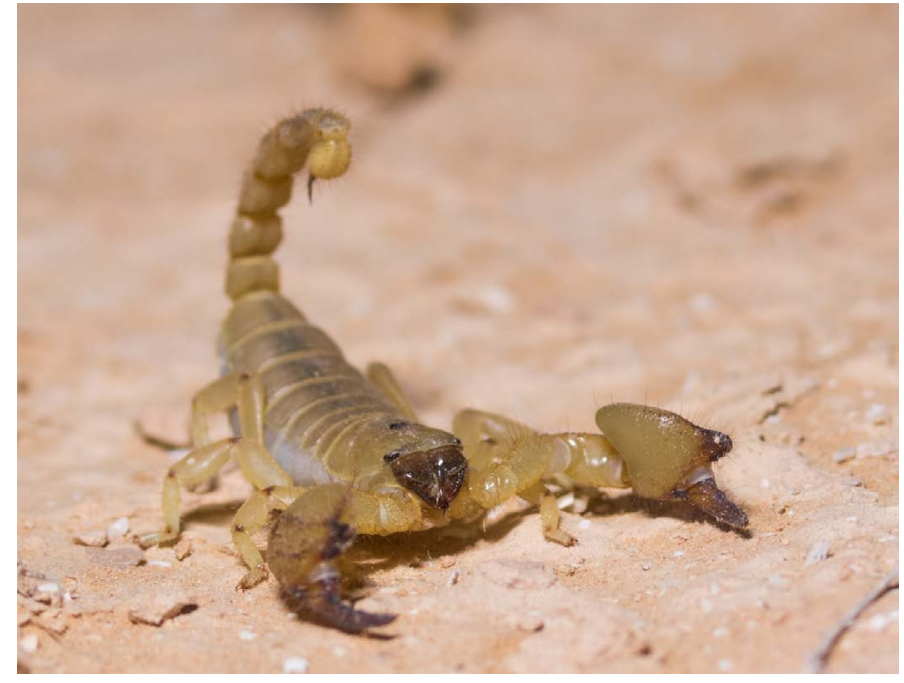

Figure 6. The Israeli gold scorpion Scorpio maurus palmatus Ehrenberg, 1828 (Arachnida, Scorpiones: Scorpionidae) (from: https://goo.gl/images/tsmDEm)

maurotoxin - which inhibit neuronal ion channel conductance [124], phospholipases A2 [125], and cytotoxins [124]. These substances probably interact synergistically to elicit the toxicity of the venom [125] that included a fast and transient hypotensive response in rats which lasted up to ten minutes, followed by a hypertensive response which lasted up to one hour [126]. Although painful, the sting is only mildly venomous to healthy humans [126].

Maurotoxin potently and selectively inhibited intermediate conductance $\mathrm{Ca}^{2+}$-activated potassium channels (IK channels) which are present in various blood cells, endothelial cells, and epithelial cells $[127,128]$, including those expressed in human $\mathrm{T}$ lymphocytes [129]. IK channels probably play an important role in the proliferative responses of $\mathrm{T}$ cells to antigenic and mitogenic stimuli by helping to maintain a large electrical gradient for the sustained influx of $\mathrm{Ca}^{2+}$ [130]. Thus, activation of T lymphocytes leads to opening of the IK channels, hyperpolarization of the membrane caused by efflux of $\mathrm{K}^{+}$ ions, and an increased influx of $\mathrm{Ca}^{2+}[130]$. T cell activation also leads to a 15- to 20-fold increase in both the amount of mRNA and the number of expressed IK channels [131].

The critical role of IK channels in T cell activation and proliferation has been confirmed in an extensive study with isolated human $\mathrm{T}$ cells which were first activated and then treated with various IK channel blockers [132]. The results from this study strongly suggested that the increase in intracellular calcium was an obligatory step in the cascade of signals that finally results in T cell proliferation [132]. This implies that $\mathrm{T}$ cell activation and proliferation may be inhibited by decreasing $\mathrm{Ca}^{2+}$ influx through obstruction of IK channel activity. Thus, IK blockers such as maurotoxin and/or some of its derivatives could be used as potential immunosuppressants for treating autoimmune disorders such as rheumatoid arthritis, inflammatory bowel disease, and multiple sclerosis [133].

Novel antimalarials: The more than twenty-three subspecies of the lesser Asian scorpion Mesobuthus eupeus Koch, 1839 (Buthidae) (Figure 7) [Teruel 2002] are found in a broad region that stretches from eastern Turkey, southern Russia, Afghanistan, and Pakistan to northern China and Australia [134]. Indeed, M. eupeus is probably the most widely dispersed species of the Mesobuthus genus, perhaps even of the family Buthidae [134]. These scorpions have a yellow to yellowbrown color and can reach a size of 4 to $5 \mathrm{~cm}$ in length [135]. They 


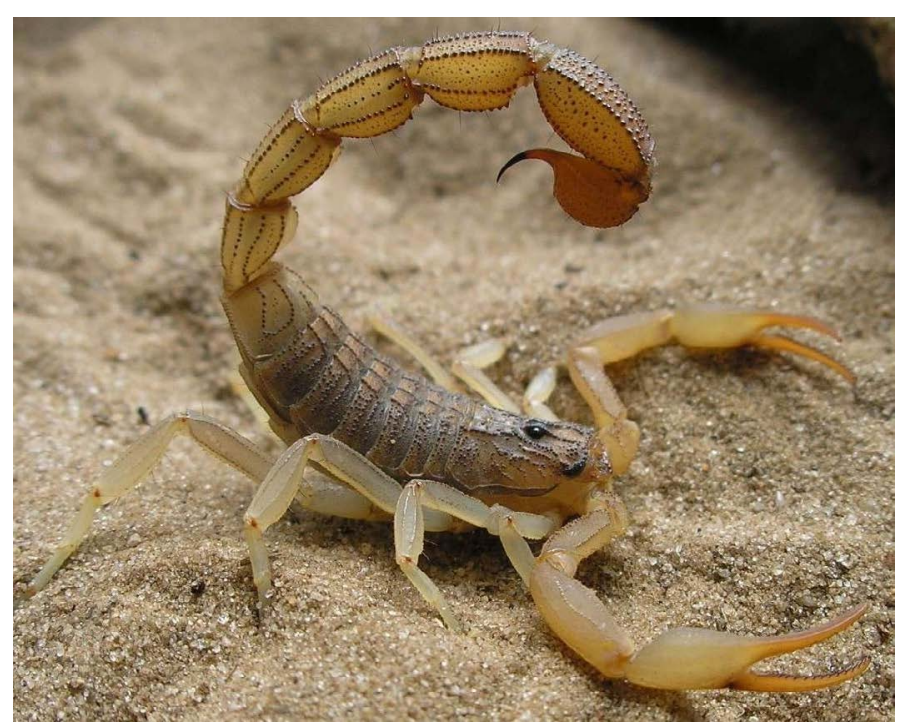

Figure 7. The lesser Asian scorpion Mesobuthus eupeus Koch, 1839 (Arachnida, Scorpiones: Buthidae) (from: https://goo.gl/images/6c9i4z)

do not dig burrows but seek for shelter in natural cavities and spaces under stones and other objects [135]. They feed on small insects such as crickets and small cockroaches which they do not catch with their slender pedipalps but immobilize with their venom [135].

The venom is not as potent as that of other buthid species but still causes intense pain, hyperemia, swelling, and a burning sensation in the affected area [136]. Similarly to that of other scorpions, $M$. eupeus venom contains various substances that specifically interact with plasma membrane constituents. Among these are not only ion channel modulators $[137,138]$ but also a number of membrane-active antimicrobial peptides called meucins. These compounds exhibited extensive cytolytic effects on, among others, Gram-positive and Gramnegative bacteria at micromolar concentrations [139]. Like many other antimicrobial peptides, meucins are believed to represent ancient biological weapons against bacteria that selectively target the bacterial cell surface [140]. The selectivity is mainly based on their cationic charge which attracts them to negatively charged groups in bacterial plasma membranes [141]. Their amphipathic nature and relatively low molecular mass $(<10 \mathrm{kDa})$ allows them to accumulate in the membranes where they form transient pores, perturb membrane integrity, and cause cell lysis [141]. Notably, the specificity of antimicrobial peptides to microbes is based on the uniquely anionic charge on bacterial plasma membranes conferring a negative charge on their surface, a feature that distinguishes (the prokaryotic) bacteria from eukaryotes whose cell surfaces are largely neutral $[142,143]$. For this reason, the interest in arthtopod antimicrobial peptides as potentially novel antibiotics is increasing [144].

Mammalian erythrocytes infected with malaria parasites undergo an alteration in the lipid composition of their plasma membrane due to the translocation of the anionic phosphatidylserine from the inner leaflet to the outer leaflet of the bilayer [145]. This results in the conversion of FITC-annexin negative, healthy erythrocytes into FITCAnnexin positive cells [146]. In other words, a Plasmodium-infected red cell mimics the anionic surface charge that characterizes the bacterial cell surface. Therefore, the infected cell should become vulnerable to the action of anti-microbial peptides. That this occurs has been observed for a variety of naturally occurring and modified antimicrobial peptides including meucin-24 and meucin-25 - consisting of 24 and 25 amino acid residues, respectively - from M. eupeus [147]. These compounds inhibited the development of Plasmodium berghei and selectively killed intraerythrocytic $P$. falciparum at micromolar concentrations while not harming normal erythrocytes and spermatogenic GC-2 cells [147]. These venom-derived proteins are therefore attractive candidates for the development of novel anti-malarial drugs.

\section{Bioactive compounds from Xiphosura}

The Xiphosura encompass a relatively small class of only four extant species in the family Limulidae which includes the horseshoe crabs [148]. They are found along the Atlantic coast of North America, and in Asia, from India to Japan and south to Malaysia and Indonesia where they live in sandy to muddy habitats or muddy areas in brackish waters $[148,149]$. They are characterized by a long telson that projects from the rear end of the body $[148,149]$, explaining their name 'Xiphosura', 'xíphos' and 'ourá' meaning 'sword' and 'tail', respectively, in ancient Greek. Horseshoe crabs are the only sea-dwelling arachnids, have hardly changed in the past 200 million years, and are considered living fossils that can be traced back to 445 million years ago [149]. Furthermore, unlike all other living chelicerates, they have compound eyes on the sides of their shells for locating mates, in addition to pairs of smaller lateral and median eyes, a single endoparietal eye, and two ventral eyes for navigation while swimming [150].

The horseshoe crab is an attractive model for vision research, and studies on the nerve pathways in the eyes have provided much insight into physiological processes operating in our visual system such as light adaptation and lateral inhibition [150,151]. This animal is also extremely important to the biomedical industry because of the presence of several unique clotting agents and antimicrobial substances in its blood cells [150-152].

Improved limulus amoebocyte lysate assay: Amoebocytes are defensive cells in the blood stream of certain horseshoe crabs - most notably the Atlantic horseshoe crab Limulus polyphemus Linnaeus, 1758 (Xiphosurida: Limulidae) (Figure 8)) - which release a coagulin in response to bacterial endotoxins that entraps the invaders, preventing infection of the animal [153]. This discovery has been taken advantage of by industrially preparing aqueous extracts from $L$. polyphemus amebocytes to give limulus amebocyte lysate (LAL) that accurately detects minute amounts of bacterial toxins or membrane

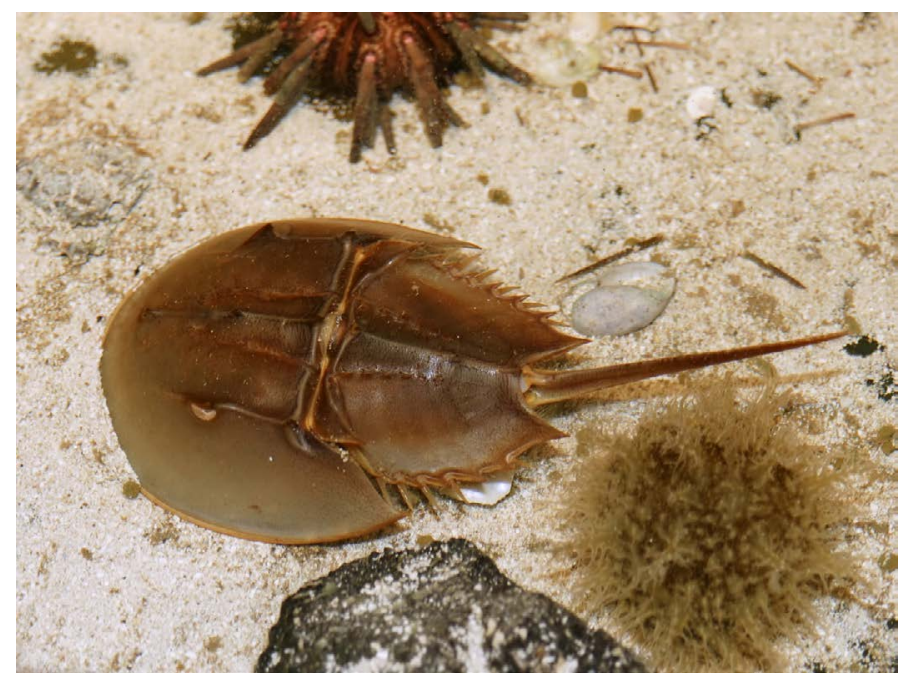

Figure 8. The Atlantic horseshoe crab Limulus polyphemus Linnaeus, 1758 (Xiphosura, Xiphosurida: Limulidae) (from: https://goo.gl/images/DsbLnq) 
lipopolysaccharides by coagulating in their presence [150-152]. LAL has extensively been used for almost forty years to test medical devices and equipment and virtually all injectable drugs for sterility [150-152].

LAL is prepared by collecting, bleeding, and harvesting blood from L. polyphemus species after which the animals are released back into the sea [154]. The animals may tolerate blood loss up to $30 \%$ and most survive the process (mortality rates are between 3 and 30\%) [154], but ethical issues and growing demands for LAL have prompted efforts to develop synthetic substitutes $[148,157]$. Extensive research efforts have been dedicated to obtain more insight into the biochemical basis of the coagulation response of horseshoe crabs. These efforts have revealed that this phenomenon involves a cascade reaction of three protease zymogens (factor $\mathrm{C}$, factor $\mathrm{B}$, and a proclotting enzyme) besides the coagulin [158]. In this cascade, the endotoxin first activates factor $C$, which then activates factor $\mathrm{B}$; factor $\mathrm{B}$, in turn, converts the proclotting enzyme into the clotting enzyme which cleaves coagulogen into coagulin [158].

These insights led to the production of recombinant analogues of the three protease zymogens of the horseshoe crab coagulation cascade that are inducible by trace levels of bacterial endotoxins [159]. The results with these compounds are so far very promising and are expected to lead to novel endotoxin assays that do not require the use of raw materials from horseshoe crabs natural resources.

Horseshoe crab-derived antibiotics: In addition to the abovementioned clotting factors, horseshoe crabs contain substances with notable antibiotic characteristics [150-152]. These compounds are called tachyplesins because tachyplesin 1 was first identified in the acid extract of hemocytes from the Japanese horseshoe crab Tachypleus tridentatus Leach, 1819 (Xiphosurida: Limulidae) (Figure 9) [160]. Since then other tachyplasins have been found, sometimes also in several other horseshoe crab species [161,162] while a number of analogues have been synthesized [163].

Tachyplasins are cationic, amphiphatic peptides composed of seventeen or eighteen amino acid residues [160-162,164]. They presumably play a role in the protection of horseshoe crabs from invading microorganisms. Indeed, these compounds were found to inhibit the growth of both Gram-negative and -positive bacteria at low concentrations $[161,164,165]$. Due to their small size, positive

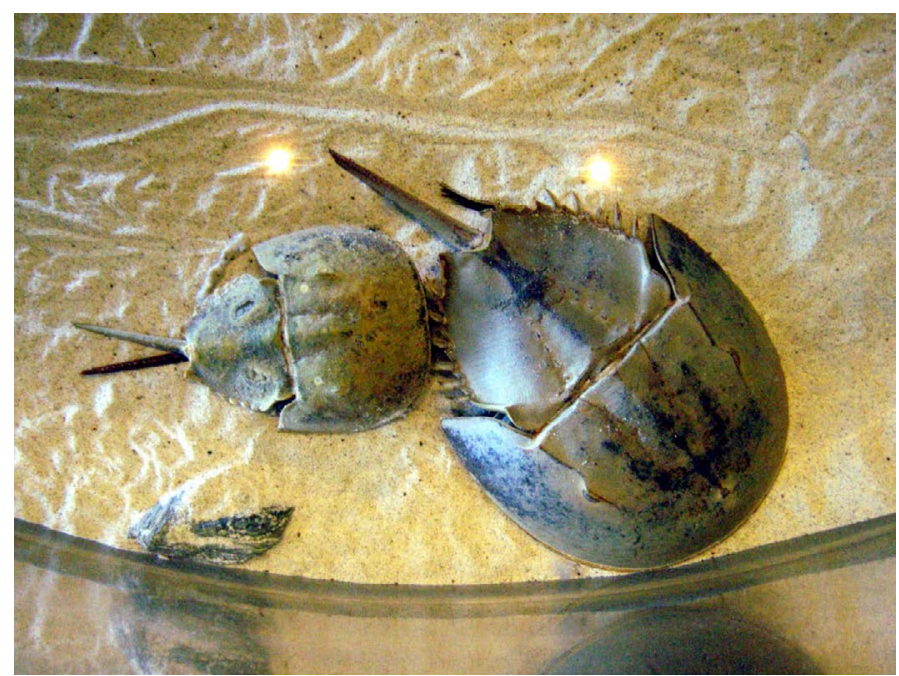

Figure 9. The Japanese horseshoe crab Tachypleus tridentatus Leach, 1819 (Xiphosura, Xiphosurida: Limulidae) (from: https://goo.gl/images/DsbLnq) net charge, and amphiphatic character, they are able to insert into bacterial membranes and to interact with the negatively charged lipopolysaccharides in bacterial membranes [160-162,164] such as lipopolysaccharides [166]. This probably leads to permeabilization and disruption of bacterial plasma membranes [166,167]. More recent studies confirmed the antibacterial activity of tachyplasins $[168,169]$ and showed that these compounds also exhibit antiviral [170], antiparasitic [171], and anticancer effects [172].

\section{Bioactive compounds from Pycnogonida}

The chelicerate class Pycnogonida (from the ancient Greek words 'pyknos' for 'thick' and 'gony' for 'knee', in reference to the shape of the joints in their legs) incorporates about 2,000 described marine arthropods in ten families that superficially resemble spiders [173]. These so-called sea spiders are encountered in many parts of the world, including Australia, New Zealand, the Pacific coast of the USA, the Mediterranean Sea, the Caribbean Sea, and the north and south poles [174]. Most are relatively small (with leg spans of less than a centimeter) and have a very thin and small body consisting of a four-segmented cephalothorax bearing four pairs of excessively long and slender legs [175]. However, a few arctic species - such as the members of the genus Colossendeis Jarzinsky, 1870 (Pantopoda: Colossendeidae) - are comparatively enormous and have leg spans of four to five centimeters [176].

Pycnogonids lack specialized respiratory or excretory structures and exchange gasses and release waste products by diffusion via the surface area of their body and legs [175]. The males typically use ovigers - special legs located between their claws and the walking legs - to carry and brood fertilized eggs [175]. Although a few species feed on algae, most are exclusively carnivorous, either feeding on sea sponges, bryozoans, cnidarians, and polychetes or scavenging dead bodies from the ocean floor [177]. Most feed by sucking the juice from their softbodied prey through their long proboscis but some species tear the prey to small pieces to eat [177]. Pycnogonids possess a disabling poison in their legs for both attacking prey and defending themselves [175] which is, unfortunately, ill-described. Some species have also been reported to produce scientifically and clinically interesting substances such as mycosporine-like amino acids.

Novel ultraviolet protection cosmetics: Mycosporine-like amino acids are small $(<400 \mathrm{Da})$ secondary metabolites that are in general produced by (marine) organisms living in environments with a high exposure to sunlight [178]. They consist of a central cyclohexenone or cyclohexenimine ring with a wide variety of substitutions [179] and protect cells from mutations by effectively absorbing ultraviolet radiation and scavenging free radicals $[178,180]$. Mycosporine-like amino acids also help to boost tolerance to desiccation, salt stress, and thermal stress $[178,180]$. These compounds have been identified in a wide variety of marine organisms such as fungi, marine heterotrophic bacteria, cyanobacteria, and eukaryotic marine invertebrates [181]. Various mycosporine-like amino acids such as palythine, porphyra-334, and shinorine have also been encountered in pycnogonid species such as Achelia spicata Hodgson, 1915 (Pantopoda: Ammotheidae) (Figure 10) [182]. In light of the remarkable qualities of mycosporine-like amino acids, these arthropod species may become important sources of natural ingredients for preparing novel ultraviolet protection cosmetics [178].

\section{Myriapoda}

The arthropod subphylum Myriapoda consists of over 16,000 mainly terrestrial species and is one of the most speciose metazoan subphyla [183]. The name is derived from the Greek words 'murios' 


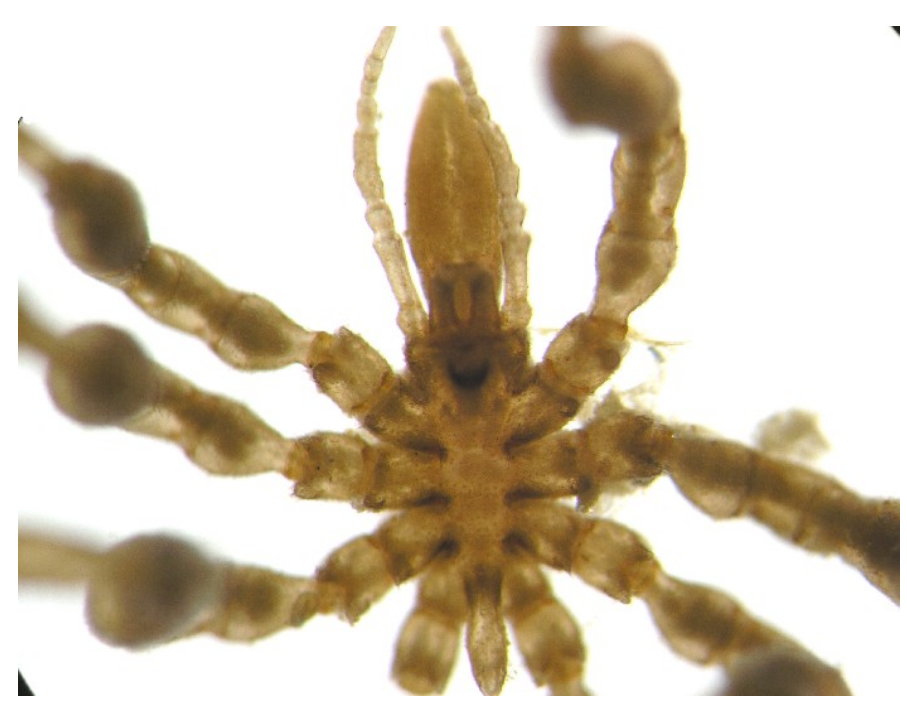

Figure 10. The sea spider Achelia spicata Hodgson, 1915 (Pycnogonida, Pantopoda: Ammotheidae) (from: https://goo.gl/images/T4dEiC)

for ' 10,000 ' and 'podos' for 'foot', in reference to their many limbs, a distinctive characteristic of this group of animals [185]. However, the number of legs in myriapods in general ranges from fewer than ten to 750 [184]. Myriapods have an elongated body consisting of two sections, the head and the trunk made up of many segments which are not fused together, typically many legs, a single pair of antenna, a single pair of mandibles, and primitive eyes [184]. The body is covered by a hard exoskeleton consisting of protein and chitin which is periodically shed when the myriapod molts and grows [184]. Growing occurs by adding segments and legs with successive molts and this process continues after sexual maturity [184].

Myriapods are mostly encountered in humid soils, leaf litters, and damp locations under stones and wood [185]. Various species are herbivorous and many are detritivorous, playing an important role in breaking down decaying plant material but most centipedes actively hunt for prey [185]. Myriapods range in size from the nearly microscopically small Pauropoda and Symphyla [186] to the thirty centimeters long millipede Illacme plenipes Cook \& Loomis, 1928 (Siphonorhinidae) discovered in California, USA, that has about 750 legs and is considered 'the world's leggiest animal' [187]. However, extinct millipedes from the genus Arthropleura Meyer, 1854 (in the extinct class Arthropleuridea) from the late Carboniferous (315 to 299 million years ago) was giant in size, having reached up to three meters in length and forty-six centimeters in width [188]. Most myriapods are generally not considered dangerous to humans, but many produce noxious secretions which can cause temporary blistering and discoloration of the skin [49-51].

The Myriapoda can be divided into four extant classes, the relatively small Pauropoda and Symphyla, as well as the two most prominent groups, the Chilopoda or centipedes and the Diplopoda or millipedes [189]. The Pauropoda (from the Greek words 'pauro' for 'few' and 'podo' for 'foot') are a sister group to the millipedes comprising around 830 species in twelve families [186]. They lack eyes and their soft, cylindrical bodies reach a length of less than two millimeters and are white- or brown-colored [186]. The Symphyla (from the Greek words 'syn' and 'phyla' for 'with' and 'types', respectively, reflecting the affinity of the group with both myriapods and insects) encompass worldwide about thirty eyeless species in two families [186]. They superficially resemble centipedes but are translucent and smaller, reaching a body length of two to ten millimeters [186]. Hereunder, some clinically important bioactive compounds from the two medicinally most important groups, the centipedes and the millipedes, are in detail addressed.

\section{Bioactive compounds from Chilopoda}

The Chilopoda (from the Greek words 'kheilos' and 'podos' for 'lip' and 'foot', respectively, because of the jaw-like appendages of the foremost pair of legs) or centipedes (from the Latin expression 'centipeda' meaning 'hundred-footed') comprise a group of about 3,300 described species within five extant orders [190]. These organisms are characterized by a very large number of segments, often well over one hundred, and the presence of one pair of legs per body segment, besides a few segments at their head and tail [190]. They range in size from Hoffman's dwarf centipede Nannarrup hoffmani Foddai, Bonato, Pereira \& Minelli, 2003 (Geophilomorpha: Mecistocephalidae) which seldom becomes longer than twelve millimeters [191], to the Peruvian giant yellow-leg centipede Scolopendra gigantea Linnaeus, 1758 (Scolopendromorpha: Scolopendridae) which may exceed thirty centimeters in length [192]. However, all have large venomous appendages called forcipules or poison claws which are modifications of the first pair of walking legs on the trunk [193].

Centipedes are relatively fast, in general nocturnal predators and mainly feed on other small arthropods, but the relatively large representatives of the order Scolopendromorpha attack and feed on bats, mice and other small mammals, snakes, frogs and toads, as well as birds [194,195]. In all cases, the prey is killed by venom injected through their fangs $[194,195]$. Venom is secreted through a pore located near the tip of each claw which is connected to one of the venom glands [196]. The venom is also used for defense against a variety of vertebrates and invertebrates such as mongooses, mice, salamanders, beetles, and snakes [194,195].

Humans are frequently stung by centipedes, particularly in tropical and subtropical regions where many of these creatures occur [197]. Fortunately, reports of human deaths due to centipede envenomation are rare and mostly attributable to secondary infections [198]. However, bites by centipedes, particularly Scolopendra spp., causes intense pain with local erythema, edema, indurations, and necrosis, and in some cases headache, malaise, and dizziness [197,199], but there are also reports of more severe (hemodynamic) symptoms [200] and anaphylaxis [201].

The relatively recent studies on the toxin arsenals of centipedes particularly those of the scolopendromorph family as well as a single scutigeromorph species - have indicated that these symptoms are for an important part attributable to the dozens of biologically active proteins, peptides, and enzymes the toxins are composed of [194,195]. Some of them are able to modulate ion channels, others have antimicrobial properties, and a few elicit in vitro anticancer effects [194,195]. For these reasons, components of centipede venoms could represent lead compounds for developing a large array of novel therapeutics [194,195]. Notably, the Chinese red-headed centipede Scolopendra subspinipes mutilans L. Koch, 1878 (Scolopendromorpha: Scolopendridae) (Figure 11) has been used for centuries in traditional Far Eastern medicine for treating, among others, spasms, childhood convulsions, seizures, poisonous nodules, and diphtheria [202].

Improved analgesics: Various neurotoxic peptides with ion channel-modulating properties have been identified in the venom of $S$. s. mutilans [203-205] and the giant Vietnamese centipede S. s. dehaani Brandt, 1840 [206]. Several of these structurally unique peptides 


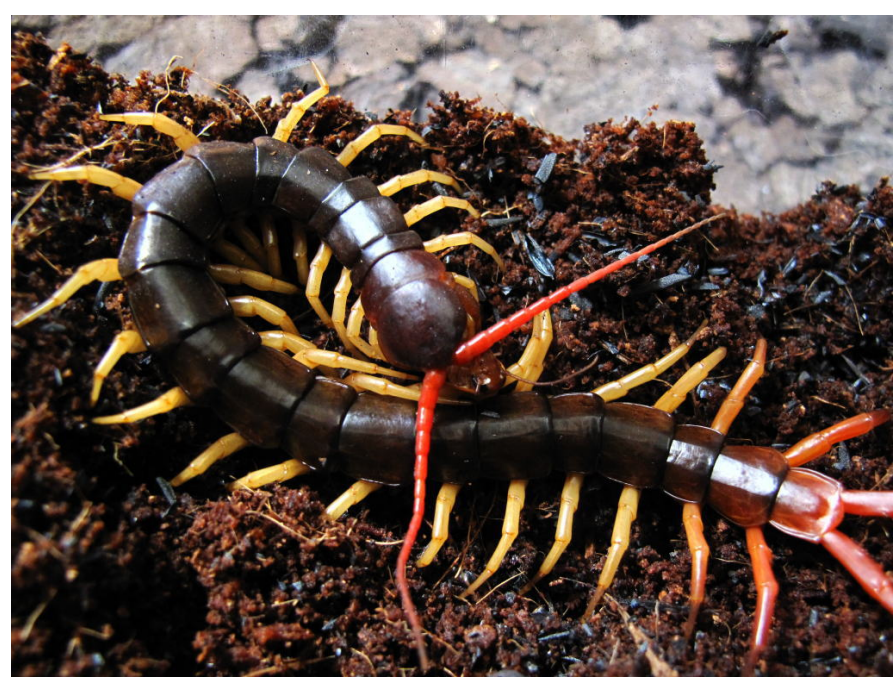

Figure 11. The Chinese red-headed centipede Scolopendra subspinipes mutilans L. Koch, 1878 (Chilopoda, Scolopendromorpha: Scolopendridae) (from: https://goo.gl/images/ W3LVsh)

targeted voltage-gated sodium, potassium, and calcium channels in the nanomolar range [203-206]. Some of them had potential insecticidal abilities [205] while others displayed platelet-aggregating, anticoagulant, phospholipase $\mathrm{A}_{2}$, and trypsin-inhibiting activity [205].

Among the more interesting ingredients of $S$. s. mutilans venom

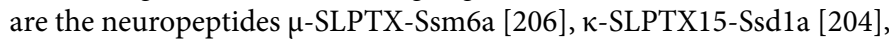
and RhTx [205]. $\mu$-SLPTX-Ssm6a potently and selectively inhibited sodium channels and elicited a greater analgesic effect than morphine in a rodent model of chemical-induced pain, and a similar effect as morphine in rodent models of thermal- and acid-induced pain [207]. $\kappa-S L P T X 15-S s d 1$ a potently blocked the widely expressed $\mathrm{K}_{\mathrm{v}} 2.1$ channel that helps control neuronal excitability [204,208]. And RhTx rapidly bound with high affinity to the capsaicin receptor TRPV1 ion channel - a polymodal nociceptor that is very sensitive to heat - causing excruciating pain by targeting the channel's heat-activation machinery at normal body temperature [205].

These observations suggest that $S$. s. mutilans venom components may become lead compounds for developing novel analgesics. $\mu$-SLPTX-Ssm6a, for instance, may treat chronic pain as efficaciously as morphine but without the side-effects of morphine [207]. Importantly, having a peripheral target, an $\mu$-SLPTX-Ssm6a-based analgesic could be given intravenously, subcutaneously, or perhaps orally, rather than intrathecally, as is the case with ziconide from the venom of marine cone snails that targets an ion channel in the central nervous system [209]. Furthermore, more detailed information about the RhTx peptide and the receptor TRPV1 ion channel may enable the construction of a structurally modified RhTx molecule that relieves pain instead of causing agony [205].

Centipede-derived antibiotics: Relatively recently, a number of antimicrobial peptides have been identified from the venom of $S$. s. mutilans. So far, these include the scolopins, the scolopendins, the scolopendrasins, and lactoferricin B-like peptide. Several of these compounds displayed potent activity against Gram-positive and Gramnegative bacteria as well as fungi while causing no or only moderate hemolysis [210-216]. The mechanism of action of these compounds may involve the activation of a potentially novel apoptotic pathway [217] following the accumulation of reactive oxygen species [214], binding to the surface of fungi or bacteria and interaction with certain membrane components $[211,218,219]$, and/or the formation of pores in the cell membrane [215].

In addition to the above-mentioned 'natural' antimicrobial peptides, a number of synthetic $S$. s. mutilans peptides have been synthesized which displayed broad antibacterial activity without causing toxicity to mouse erythrocytes [220]. Furthermore, a novel peptide called lacrain, was identified from extracts of the Indo-Burmese centipede Scolopendra viridicornis Newport, 1844 (Scolopendridae) that was only active against Gram-negative bacteria and also had no effect on human erythrocytes [221]. Thus, centipede antimicrobial peptides may yield both candidates for screening and lead compounds for developing more efficacious antibiotics.

Novel anticancer agents: Several studies also reported anticancer effects of centipede extracts. For instance, the ethanol extract of $S$. $s$. mutilans inhibited the proliferation of cultured A375 cell human melanoma cells and arrested them at the $S$ phase of their cell cycle [222]. Furthermore, the extracts markedly induced apoptosis which was associated with a decrease in the expression of the anti-apoptotic protein Bcl-2 and an increase in those of the pro-apoptotic proteins Bak, Bax, and Bad [222]. A subsequent study showed that the Scolopendra extract was particularly active against tumor cells that overexpressed the epidermal growth factor receptor (EGFR) such as A431 human epidermoid carcinoma and HEK293/EGFR human embryonic kidney cells [223]. This effect has been attributed to modulation of the EGFR pathway and its downstream elements involved in apoptosis [223].

These results were consistent with those found earlier with a mouse model of cervical carcinoma, the growth of which was suppressed by ether and alcohol extracts from S. s mutilans [224]. The compound responsible for these actions remains to be identified. However, the cationic antimicrobial peptide scolopendrasin VII from S. $s$ mutilans induced necrotic cell death in cultured U937 and Jurkat leukemia cells, probably through interaction with phosphatidylserine on the surface of the cells [225]. And jineol, a quinoline alkaloid isolated from this centipede, exhibited (modest) in vitro cytotoxicity against A-549 adenocarcinomic human alveolar basal epithelial cells, SKOV3 human ovarian carcinoma cells, SK-MEL-2 human melanoma cells, XF-498 human glioblastoma cells, and HCT-15 human colorectal carcinoma cells [226]. Thus, although much work still lays ahead, these data suggest that centipedes may contain compounds with potential antineoplastic effects and support the previous claims of such actions of substances from these arthropods [202].

\section{Bioactive compounds from Diplopoda}

The Diplopoda (from the Greek words 'diplous' and 'podos' for 'double' and 'foot', respectively, indicating the presence of two pairs of legs on most segments) or millipedes (a compound word from the Latin roots 'millia' for thousand and 'pes' for foot) encompass over 8,000 described species, representing the most species-rich class of the myriapods [227]. Diplopoda have in general a larger number of segments and appendages than Chilopoda [228,229]. As mentioned above, one species of Diplopoda, the California millipede I. plenipes has 750 legs, making it the animal with the largest number of legs on Earth [187].

Millipedes and centipedes often share the same habitats [230] but they differ from each other with respect to two main aspects. Firstly, the body segments of millipedes - unlike those of centipedes - are formed in early development by fusion of two adjacent embryonic segments, giving the appearance in adulthood of having two pairs of legs per 
Table 1. (Potential) medicinal applications of arthropod constituents

\begin{tabular}{|l|l|l|l|}
\hline Subphylum & Class, order & Putative bioactive constituent(s) \\
\hline Chelicerata & Arachnida, Araneae ('true' spiders) & Neurotoxic peptides & Application(s) \\
\hline & & Neurotoxic peptides & Erectogenic conditions \\
\hline & Arachnida, Scorpiones (scorpions) & Neurotoxic peptides & Neurotoxic peptides \\
\hline & & Membrane-active peptides & Diagnoses and therapy of gliomas \\
\hline & Arachnida, Xiphosura (horseshoe crabs) & Coagulants & Antimalarials \\
\hline & & Improved limulus amoebocyte lysate assay \\
\hline Myriapoda & Arachnida, Pycnogonida (sea spiders) & Mycosporine-like amino acids \\
\hline & Chilopoda (centipedes) & Neurotoxic peptides \\
\hline & & Membrane-active peptides \\
\hline & & Membrane-active peptides \\
\hline
\end{tabular}

segment $[228,229]$. Secondly, millipedes are in general slower than centipedes, do not have fangs, and mostly feed on leaf litter and detritus instead of hunting for prey [230]. However, many millipedes exude foul-smelling, unpalatable, or toxic substances from their repugnatorial glands along the sides of their bodies near their legs as defense against predators such as ants, beetles, predaceous bugs, spiders, slugs, as well as various birds, mammals, reptiles, and amphibians [229].

Millipede-derived antibiotics: As mentioned in the 'Background' section of this paper, one of the chemical defenses of millipedes is hydrogen cyanide gas that is mainly produced by members of the Polydesmida [50,51]. Different taxonomic groups also produce a variety of other defensive chemicals such as alkaloids (by the orders Glomerida and Polyzoniida [231,232]); phenolic compounds (by the orders Callipodida [233] and Julida [234,235]); as well as benzoquinones (particularly the orders Spirobolida, Spirostreptida [236,237] and Julida [234,235]).

The hydrogen cyanide gas interferes with cellular respiration and is obviously is highly poisonous [238]; the alkaloids may have a deterrent effect on potential predators [239]; the phenolics probably act as effective repellents due to their obtrusive odor [240]; and the benzoquinones are strongly irritant, causing staining and burning of the skin as well as lacrimation, keratitis, and ulceration of the cornea when reaching the eyes $[38,241]$. For these reasons, various mammals and birds self-anoint with certain millipedes, i.e., roll on or rub themselves with the secretions of these creatures, a behavior believed to have evolved in order to keep ectoparasites away from their integument $[53,242,243]$. Support for this theory is the strong deterrent effect of millipedes' secretions on mosquitoes [53].

Converging research data [244-246] suggest that the defensive secretions of certain polydesmid and julid millipedes also have meaningful antimicrobial, antiparasitic, and antifungal qualities. This held particularly true for the benzoquinones [51,237,247,248]. Notably, the two dominant quinones in the defensive secretion of Pachyiulus hungaricus (Karsch, 1881) (Julida, Julidae) (Figure 12), 2-methyl1,4,-benzoquinone and 2-methoxy-3-methyl-1,4-benzoquinone, elicited meaningful antibacterial and antifungal activity, including activity against methicillin-resistant Staphylococcus aureus [249]. These observations suggest that particularly the antimicrobial quinones from millipede species may be useful as lead compounds of a new class of antibiotics.

\section{Concluding remarks}

This paper has reviewed a handful of therapeutically applicable bioactive compounds from spiders, scorpions, horseshoe crabs, sea spiders, centipedes, and millipedes. Further exploration of these

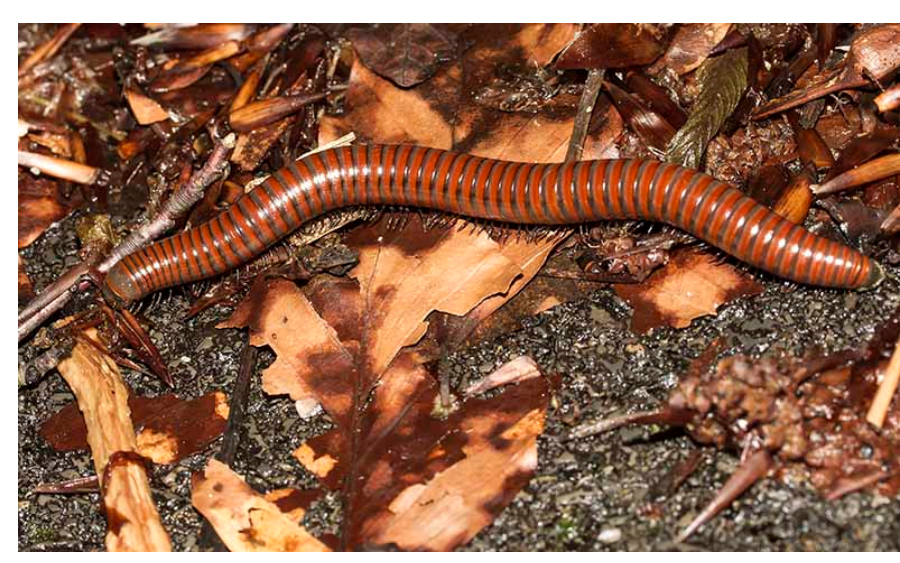

Figure 12. The millipede Pachyiulus hungaricus (Karsch, 1881) (Diplopoda, Julida: Julidae) (from: https://goo.gl/images/bmSEy6)

compounds may lead to the development of valuable medicines for treating, among others, erectogenic conditions [76-78], botulism [97,98], malignant neoplasms [114,116,222,223], autoimmune disorders [133], microbial [161,165,210,215,245] and parasitic infections [147], and chronic pain [207], as well as improved bacterial endotoxin detection [159] and innovative sunscreens [178]. These advances are much needed when considering the high global incidence of erectogenic conditions [250], autoimmune disorders [251], and cancer [252], the worldwide threat of bioterrorism [99], and the increasing resistance of microbial [253] and parasitic infections [254] to exisiting medications. Importantly, the very high specificity and potency for particular molecular targets of these compounds is likely to guarantee excellent therapeutic efficacy with minimal toxicity.

The abundance of arthropods producing an extraordinarily diverse range of potentially therapeutic ingredients in their venomous secretions is likely to yield a multitude of other clinically useful compounds. A few examples are ingredients in spider and scorpion venoms for treating cardiac arrhythmia, central nervous system degenerative diseases, asthma, and strokes [194,255-260]. Some of these substances may also lead to important industrial applications. For instance, many spider venoms are deadly to insects but harmless to vertebrates and may be a less polluting alternative to conventional pesticides [261], while the 2-pyrrolidinone in the silk of $N$. antipodiana could lead to the development of a new insect repellent for human use [45]. Notably, the relatively recent discovery of the small crustacean class Remipedia [262] that appeared to produce a unique cocktail of digestive enzymes and neurotoxins to paralyze their prey [26] hints to the existence of many more exceptional arthropod-based bioactive molecules. 
Critically important to these new drug discovery and development efforts is the identification of the principal ingredients in the venom and their specific molecular targets in human cells in order to acquire lead compounds that can subsequently be improved to candidates for preclinical and clinical studies. Fortunately, contemporary molecular biology techniques enable the rapid production of sufficient recombinant toxins as well as many analogues to eventually design 'ideal' drugs $[263,264]$. It is safe to say that these developments will emerge in the near future.

\section{References}

1. Mans DRA (2013) From forest to pharmacy: plant-based traditional medicines as sources for novel therapeutic compounds. Acad J Med Plants 1: 101-110.

2. Sen T, Samanta SK (2015) Medicinal plants, human health and biodiversity: a broad review. Adv Biochem Eng Biotechnol 147: 59-110. [Crossref]

3. Wick JY (2012) Aspirin: a history, a love story. Consult Pharm 27: 322-329. [Crossref]

4. Priyadarshini K, Keerthi Aparajitha U (2012) Paclitaxel against cancer: A short review. Med Chem 2: 139-141.

5. Unti E, Ceravolo R, Bonuccelli U (2015) Apomorphine hydrochloride for the treatment of Parkinson's disease. Expert Rev Neurother 15: 723-732. [Crossref]

6. Halpin DM, Vogelmeier C, Pieper MP, Metzdorf N, Richard F, et al. (2016) Effect of tiotropium on COPD exacerbations: a systematic review. Respir Med 114: 1-8. [Crossref]

7. Ansari MT, Saify ZS, Sultana N, Ahmad I, Saeed-Ul-Hassan S, et al. (2013) Malaria and artemisinin derivatives: an updated review. Mini Rev Med Chem 13: 1879-1902. [Crossref]

8. Seltzer B (2010) Galantamine-ER for the treatment of mild-to-moderate Alzheimer's disease. Clin Interv Aging 5: 1-6. [Crossref]

9. Jimenez K, Kulnigg-Dabsch S, Gasche C (2015) Management of iron deficiency anemia. Gastroenterol Hepatol (N Y) 11: 241-250. [Crossref]

10. Gupta M, Mahajan VK, Mehta KS, Chauhan PS (2014) Zinc therapy in dermatology: a review. Dermatol Res Pract 2014: 709152. [Crossref]

11. Clark P, Tugwell P, Bennet K, Bombardier C, Shea B, et al. (2000) Injectable gold for rheumatoid arthritis. Cochrane Database Syst Rev : CD000520. [Crossref]

12. Demain AL, Elander RP (1999) The beta-lactam antibiotics: past, present, and future. Antonie Van Leeuwenhoek 75: 5-19. [Crossref]

13. Abastado P (2006) 20th century at a glance: the streptomycin story. Med Sci (Paris) 22: 544-547. [Crossref]

14. Kumar CG, Himabindu M, Jetty A (2008) Microbial biosynthesis and applications of gentamicin: a critical appraisal. Crit Rev Biotechnol 28: 173-212. [Crossref]

15. Rajakumar K (2003) Vitamin D, cod-liver oil, sunlight, and rickets: a historical perspective. Pediatrics 112: e132-135. [Crossref]

16. Vane JR (1999) The history of inhibitors of angiotensin-converting enzyme. J Physiol Pharmacol 50: 489-498. [Crossref]

17. Bhavnani BR, Stanczyk FZ2 (2014) Pharmacology of conjugated equine estrogens: efficacy, safety and mechanism of action. J Steroid Biochem Mol Biol 142: 16-29. [Crossref]

18. Kamiya H, Sakai R, Jimbo M (2006) Bioactive molecules from sea hares. Prog $\mathrm{Mol}$ Subcell Biol 43: 215-239. [Crossref]

19. Gademann K, Kobylinska J (2009) Antimalarial natural products of marine and freshwater origin. Chem Rec 9: 187-198. [Crossref]

20. Mir R, Karim S, Kamal MA, Wilson CM, Mirza Z (2016) Conotoxins: structure, therapeutic potential and pharmacological applications. Curr Pharm Des 22: 582-589. [Crossref]

21. Deng LP, Dong J, Cai H, Wang W (2013) Cantharidin as an antitumor agent: a retrospective review. Curr Med Chem 20: 159-166. [Crossref]

22. Dongol Y, Dhananjaya BL, Shrestha RK, Aryal G (2016) Wasp venom toxins as a potential therapeutic agent. Protein Pept Lett 23: 688-698. [Crossref]

23. Cornara L, Biagi M, Xiao J, Burlando B (2017) Therapeutic properties of bioactive compounds from different honeybee products. Front Pharmacol 8: 412. [Crossref]

24. Mans DRA (2016) Exploring the global animal biodiversity in the search for new drugs - marine invertebrates. J Transl Sci 2: 170-179.
25. Mans DRA, Shellice S, Ganga D, Kartopawiro J (2016) Exploring the global animal biodiversity in the search for new drugs - insects. J Transl Sci 3: 371-386.

26. Yager J (1981) Remipedia, a new class of Crustacea from a marine cave in the Bahamas. J Crustac Biol 1: 328-333.

27. Von Reumont BM, Blanke A, Richter S, Alvarez F, Bleidorn C, et al. (2014) The first venomous crustacean revealed by transcriptomics and functional morphology: remipede venom glands express a unique toxin cocktail dominated by enzymes and a neurotoxin. Mol Biol Evol 31: 1 48-58. [Crossref]

28. Budd GE, Telford MJ (2009) The origin and evolution of arthropods. Nature 457: 812 817. [Crossref]

29. Ødegaard F (2000) How many species of arthropods? Erwin's estimate revised. Biol J Linnean Soc 71: 583-597.

30. Powell GC (1974) Gregarious king crabs. Sea Front 20: 206-211.

31. Boxshall GA, Jaume D (2000) Making waves: the repeated colonization of fresh water by copepod crustaceans. Adv Ecol Res 31: 61-79.

32. Osorio D, Averof M, Bacon JP (1995) Arthropod evolution: great brains, beautiful bodies. Trends Ecol Evol 10: 449-454. [Crossref]

33. Johnson NF, Triplehorn CA (2005) Borror and DeLong's introduction to the study of insects. (7thedtn). Cengage Learning, Boston (MA), USA.

34. Gullan PJ, Cranston PS (2014) The insects: an outline of entomology. (5thedtn). John Wiley and Sons, Chichester, West Sussex, UK.

35. Tricarico E, Gherardi F (2006) Shell acquisition by hermit crabs: which tactic is more efficient? Behav Ecol Sociobiol 60: 492-500.

36. Stachowicz JJ, Hay ME (1999) Reducing predation through chemically mediated camouflage: indirect effect of plant defences on herbivores. Ecol 80: 2085-2101.

37. Maruzzo D, Bonato L, Brena C, Fusco G, Minelli A (2005) Appendage loss and regeneration in arthropods: a comparative view. Crustacean Issues 16, Crustacea and Arthropod Relationships. CRC Press, Boca Raton, USA. Pp. 214-245.

38. Haddad Jr V, de Amorim PCH, Haddad Jr WT, Cardoso JLC (2015) Venomous and poisonous arthropods: identification, clinical manifestations of envenomation, and treatments used in human injuries. Rev Soc Bras Med Trop 48: 650-657. [Crossref]

39. Prestwich GD, Chen D (1981) Soldier defense secretions of Trinervitermes bettonianus (Isoptera, Nasutitermitinae): chemical variation in allopatric populations. J Chem Ecol 7: $147-157$.

40. Jones TH, Clark DA, Edwards AA, Davidson DW, Spande TF, et al. (2004) The chemistry of exploding ants, Camponotus spp. (cylindricus complex). J Chem Ecol 30: 1479-1492. [Crossref]

41. Dean J, Aneshansley DJ, Edgerton HE, Eisner T (1990) Defensive spray of the bombardier beetle: a biological pulse jet. Science 248: 1219-1221. [Crossref]

42. Whitman DW, Billen JPJ, Alsop D, Blum MS (1991) Anatomy, ultrastructure, and functional morphology of the metathoracic tracheal defensive glands of the grasshopper Romalea guttata. Can J Zool 69: 2100-2108.

43. Machado G, Bonato V, Oliveira PS (2002) Alarm communication: a new function for the scent-gland secretion in harvestmen (Arachnida: Opiliones). Naturwissenschaften 89: 357-360. [Crossref]

44. Machado G, Carrera PC, Pomini AM, Marsaioli AJ (2005) Chemical defense in harvestmen (Arachnida, Opiliones): do benzoquinone secretions deter invertebrate and vertebrate predators? J Chem Ecol 31: 2519-2539. [Crossref]

45. Zhang S, Koh TH, Seah WK, Lai YH, Elgar MA, et al. (2012) A novel property of spider silk: chemical defence against ants. Proc Biol Sci 279: 1824-1830. [Crossref]

46. Bertani R, Boston T Evennou Y, Guadanucci JPL (2003) Release of urticating hairs by Avicularia versicolor (Walckenaer, 1837) (Araneae, Theraphosidae). Bull Br Arachnol Soc 12: 395-398.

47. Eisner T, Eisner M, Deyrup M (1996) Millipede defense: use of detachable bristles to entangle ants. Proc Natl Acad Sci U S A 93: 10848-10851. [Crossref]

48. Inceoglu B, Lango J, Jing J, Chen L, Doymaz F, et al. (2003) One scorpion, two venoms: prevenom of Parabuthus transvaalicus acts as an alternative type of venom with distinct mechanism of action. Proc Natl Acad Sci U S A 100: 922-927. [Crossref]

49. Eisner T, Alsop D, Hicks K, Meinwald J (1978) Defensive secretions of millipedes. Arthropod Venoms, Handbook of Experimental Pharmacology, vol. 48. SpringerVerlag, pp. 41e72. 
Mans DRA (2017) Exploring the global animal biodiversity in the search for new drugs - Spiders, scorpions, horseshoe crabs, sea spiders, centipedes, and millipedes

50. Conner WE, Jones TH, Eisner T, Meinwald J (1977) Benzoyl cyanide in the defensive secretion of polydesmoid millipeds. Experientia 33: 206-207. [Crossref]

51. Makarov SE, Curcić BP, Tesević VV, Jadranin MB, Vujisić LV, et al. (2010) Defensive secretions in three species of polydesmids (Diplopoda, Polydesmida, Polydesmidae). $J$ Chem Ecol 36: 978-982. [Crossref]

52. Tuf IH, Cmielová L, Šipoš J (2016) Conglobation as a defensive behaviour of pill millipedes (Diplopoda: Glomerida). Acta Soc Zool Bohem 80: 39-44.

53. Weldon PJ, Aldrich JR, Klun JA, Oliver JE, Debboun M (2003) Benzoquinones from millipedes deter mosquitoes and elicit self-anointing in capuchin monkeys (Cebus spp.). Naturwissenschaften 90: 301-304. [Crossref]

54. Weygoldt P (1998) Evolution and systematics of the Chelicerata. Experimental \& Applied Acarology 22: 63-79.

55. Dunlop JA. (2010) Geological history and phylogeny of Chelicerata. Arthropod Struct Dev 39: 124-142. [Crossref]

56. Giribet G, Sharma PP (2015) Evolutionary biology of harvestmen (Arachnida, Opiliones). Annu Rev Entomol 60: 157-175. [Crossref]

57. Gnaspini P (1998) Chemical and behavioral defenses of a neotropical cavernicolous harvestman: Goniosoma spelaeum (Opiliones, Laniatores, Gonyleptidae). J Arachnol 26: 81-90.

58. Jongejan F, Uilenberg G (2004) The global importance of ticks. Parasitology 129 Suppl: S3-14. [Crossref]

59. Shapiro ED (2014) Clinical practice. Lyme disease. N Engl J Med 370: 1724-1731. [Crossref]

60. Masters EJ, Olson GS, Weiner SJ, Paddock CD (2003) Rocky Mountain spotted fever: a clinician's dilemma. Arch Intern Med 163: 769-774. [Crossref]

61. Kurachi Y, North A (2004) Ion channels: their structure, function and control - an overview. J Physiol 554: 245-247. [Crossref]

62. Catterall WA, Cestèle S, Yarov-Yarovoy V, Yu FH, Konoki K, et al. (2007) Voltagegated ion channels and gating modifier toxins. Toxicon 49: 124-141. [Crossref]

63. Spillane J, Kullmann DM, Hanna MG (2016) Genetic neurological channelopathies: molecular genetics and clinical phenotypes. J Neurol Neurosurg Psychiatry 87: 37-48. [Crossref]

64. Kalia J, Milescu M, Salvatierra J, Wagner J, Klint JK, et al. (2015) From foe to friend: using animal toxins to investigate ion channel function. $J$ Mol Biol 427: 158-175. [Crossref]

65. Morales-Lázaro SL, Hernández-García E, Serrano-Flores B, Rosenbaum T1 (2015) Organic toxins as tools to understand ion channel mechanisms and structure. Curr Top Med Chem 15: 581-603. [Crossref]

66. Coddington JA, Levi HW (1991) Systematics and evolution of spiders (Araneae). Annu Rev Ecol Syst 22: 565-592.

67. Forster RR, Platnick NI (1977) A review of the spider family Symphytognathidae (Arachnida, Araneae). Am Mus Novit 2619: 1-29.

68. Selden PA, Corronca JA, Hünicken MA (2005) The true identity of the supposed giant fossil spider Megarachne. Biol Lett 1: 44-48. [Crossref]

69. Meehan CJ, Olson EJ, Reudink MW, Kyser TK, Curry RL (2009) Herbivory in a spider through exploitation of an ant-plant mutualism. Curr Biol 19: R892-893. [Crossref]

70. Clark RF, Wethern-Kestner S, Vance MV, Gerkin R (1992) Clinical presentation and treatment of black widow spider envenomation: A review of 163 cases. Ann Emerg Med 21: 782-787. [Crossref]

71. Nicholson GM, Graudins A, Wilson HI, Little M, Broady KW (2006) Arachnid toxinology in Australia: from clinical toxicology to potential applications. Toxicon 48 872-898. [Crossref]

72. Simó M, Brescovit AD (2001) Revision and cladistic analysis of the Neotropical spider genus Phoneutria Perty, 1833 (Araneae, Ctenidae), with notes on related Ctenidae. Bull Br Arachnol Soc 12: 67-82.

73. Bucaretchi F, Mello SM, Vieira RJ, Mamoni RL, Blotta MH, et al. (2008) Systemic envenomation caused by the wandering spider Phoneutria nigriventer, with quantification of circulating venom. Clin Toxicol 46: 885-889. [Crossref]

74. Gomez MV, Kalapothakis E, Guatimosim C, Prado MA (2002) Phoneutria nigriventer venom: a cocktail of toxins that affect ion channels. Cell Mol Neurobiol 22: 579-588. [Crossref]
75. Senff-Ribeiro A, da Silva PH, Chaim OM, Gremski LH, Paludo KS, et al. (2008) Biotechnological applications of brown spider (Loxosceles genus) venom toxins. Biotechnol Adv 26: 210-218. [Crossref]

76. Yonamine CM, Troncone LR, Camillo MA (2004) Blockade of neuronal nitric oxide synthase abolishes the toxic effects of Tx2-5, a lethal Phoneutria nigriventer spider toxin. Toxicon 44: 169-172. [Crossref]

77. Nunes KP, Costa-Gonçalves A, Lanza LF, Cortes SF, Cordeiro MN, et al. (2008) Tx2-6 toxin of the Phoneutria nigriventer spider potentiates rat erectile function. Toxicon 51: 1197-1206. [Crossref]

78. Nunes KP, Torres FS, Borges MH, Matavel A, Pimenta AM, et al. (2013) New insights on arthropod toxins that potentiate erectile function. Toxicon 69: 152-159. [Crossref]

79. Matavel A, Fleury C, Oliveira LC, Molina F, De Lima ME, et al. (2009) Structure and activity analysis of two spider toxins that alter sodium channel inactivation kinetics. Biochemistry 48: 3078-3088. [Crossref]

80. Nunes KP, Wynne BM, Cordeiro MN, Borges MH, Richardson M, et al. (2012) Increased cavernosal relaxation by Phoneutria nigriventer toxin, PnTx2-6, via activation at NO/cGMP signaling. Int J Impot Res 24: 69-76. [Crossref]

81. Nunes KP, Toque HA, Borges MH, Richardson M, Webb RC, et al. (2012) Erectile function is improved in aged rats by PnTx2-6, a toxin from Phoneutria nigriventer spider venom. $J$ Sex Med 9: 2574-2581. [Crossref]

82. Andrade E, Villanova F, Borra P, Leite K, Troncone L, et al. (2008) Penile erection induced in vivo by a purified toxin from the Brazilian spider Phoneutria nigriventer. BJU Int 102: 835-837. [Crossref]

83. Chitaley K, Webb RC, Dorrance AM, Mills TM (2001) Decreased penile erection in DOCA-salt and stroke prone-spontaneously hypertensive rats. Int J Impot Res 13 (Suppl 5): S16-S20. [Crossref]

84. Leite KR, Andrade E, Ramos AT, Magnoli FC, Srougi M, et al. (2012) Phoneutria nigriventer spider toxin $\mathrm{T} \times 2-6$ causes priapism and death: a histopathological investigation in mice. Toxicon 60: 797-801. [Crossref]

85. Silva CN, Nunes KP, Torres FS, Cassoli JS, Santos DM, et al. (2015) PnPP-19, a synthetic and nontoxic peptide designed from a Phoneutria nigriventer toxin, potentiates erectile function via NO/cGMP. J Urol 194: 1481-1490. [Crossref]

86. Garb JE, González A, Gillespie RG (2004) The black widow spider genus Latrodectus (Araneae: Theridiidae): phylogeny, biogeography, and invasion history? $\mathrm{Mol}$ Phylogenet Evol 31: 1127-1142. [Crossref]

87. Segoli M, Arieli R, Sierwald P, Harari AR, Lubin Y (2008) Sexual cannibalism in the brown widow spider (Latrodectus geometricus). Ethology 114: 279-286.

88. Jelinek GA (1997) Widow spider envenomation (latrodectism): a worldwide problem. Wilderness Environ Med 8: 226-231. [Crossref]

89. Akhunov A, Golubenko Z, Abdurashidova NA, Mustakimova EC, Ibragimov FA, et al (2001) Comparative biochemistry of the physiologically active components of venom, hemolymphy, and eggs of the karakurt spider (Latrodectus tredecimguttatus). Chem Nat Compd 37: 562-565. [Crossref]

90. Camp NE (2014) Black widow spider envenomation. J Emerg Nurs 40: 193-194. [Crossref]

91. Khvotchev M, Südhof TC (2000) alpha-latrotoxin triggers transmitter release via direct insertion into the presynaptic plasma membrane. EMBO J 19: 3250-3262. [Crossref]

92. Grasso A (1976) Preparation and properties of a neurotoxin purified from the venom of black widow spider (Latrodectus mactans tredecimguttatus). Biochim Biophys Acto 439: 406-412. [Crossref]

93. Krasnoperov VG, Shamotienko OG, Grishin EV (1990) Isolation and properties of insect-specific neurotoxins from venoms of the spider Lactodectus mactans tredecimguttatus. Bioorg Khim 16: 1138-1140. [Crossref]

94. Duan Z, Yan X, Cao R, Liu Z, Wang X, et al. (2008) Proteomic analysis of Latrodectus tredecimguttatus venom for uncovering potential latrodectism-related proteins. $J$ Biochem Mol Toxicol 22: 328-336. [Crossref]

95. Ushkaryov YA, Volynski KE, Ashton AC (2004) The multiple actions of black widow spider toxins and their selective use in neurosecretion studies. Toxicon 43: 527-542. [Crossref]

96. Ushkaryov YA, Rohou A, Sugita S (2008) alpha-Latrotoxin and its receptors. Handb Exp Pharmacol : 171-206. [Crossref]

97. Simpson LL (2004) Identification of the major steps in botulinum toxin action. Annu Rev Pharmacol Toxicol 44: 167-193. [Crossref] 
Mans DRA (2017) Exploring the global animal biodiversity in the search for new drugs - Spiders, scorpions, horseshoe crabs, sea spiders, centipedes, and millipedes

98. Mesngon M, McNutt P (2011) a-latrotoxin rescues SNAP-25 from BoNT/A-mediated proteolysis in embryonic stem cell-derived neurons. Toxins 3: 489-503. [Crossref]

99. Pal M, Tsegaye M, Girzaw F, Bedada H, Godishala V, et al. (2017) An overview on biological weapons and bioterrorism. Am J Biomed Res 5: 24-34.

100. Prendini L, Wheeler WC (2005) Scorpion higher phylogeny and classification, taxonomic anarchy, and standards for peer review in online publishing. Cladistics 21: 446-494.

101. Volschenk ES, Mattoni CI, Prendini L (2008) Comparative anatomy of the mesosomal organs of scorpions (Chelicerata, Scorpiones), with implications for the phylogeny of the order. Zool J Linnean Soc 154: 651-675.

102. Chippaux JP1, Goyffon M (2008) Epidemiology of scorpionism: a global appraisal. Acta Trop 107: 71-79. [Crossref]

103. Devarbhavi PK, Vasudeva Murthy CR (2013) Scorpion sting envenomation - an overview. J Clin Biomed Sci 3: 159-166.

104. DeBin JA, Maggio JE, Strichartz GR (1993) Purification and characterization of chlorotoxin, a chloride channel ligand from the venom of the scorpion. Am J Physiol 264: C361-369. [Crossref]

105. Sofer S, Shahak E, Slonim A, Gueron M (1991) Myocardial injury without heart failure following envenomation by the scorpion Leiurus quinquestriatus in children. Toxicon 29: 382-385. [Crossref]

106. DeBin JA, Strichartz GR (1991) Chloride channel inhibition by the venom of the scorpion Leiurus quinquestriatus. Toxicon 29: 1403-1408. [Crossref]

107. Soroceanu L, Gillespie Y, Khazaeli MB, Sontheimer H (1998) Use of chlorotoxin for targeting of primary brain tumors. Cancer Res 58: 4871-4879. [Crossref]

108. Ullrich N, Bordey A, Gillespie GY, Sontheimer H (1998) Expression of voltageactivated chloride currents in acute slices of human gliomas. Neuroscience 83: 11611173. [Crossref]

109. Veiseh M, Gabikian P, Bahrami SB, Veiseh O, Zhang M, et al. (2007) Tumor paint: a chlorotoxin: and Cy5.5 bioconjugate for intraoperative visualization of cancer foci. Cancer Res 67: 6882-6888. [Crossref]

110. Lyons SA, O'Neal J, Sontheimer H (2002) Chlorotoxin, a scorpion-derived peptide, specifically binds to gliomas and tumors of neuroectodermal origin. Glia 39: 162173. [Crossref]

111. Mamelak AN, Jacoby DB (2007) Targeted delivery of antitumoral therapy to glioma and other malignancies with synthetic chlorotoxin (TM-601). Expert Opin Drug Deliv 4: 175-186. [Crossref]

112. Olsen ML, Schade S, Lyons SA, Amaral MD, Sontheimer H (2003) Expression of voltage-gated chloride channels in human glioma cells. J Neurosci 23: 5572-5582. [Crossref]

113. Turner KL, Sontheimer $\mathrm{H}$ (2014) $\mathrm{Cl}$ - and $\mathrm{K}+$ channels and their role in primary brain tumour biology. Philos Trans R Soc Lond B Biol Sci 369: 20130095. [Crossref]

114. Soroceanu L, Manning TJ Jr, Sontheimer H (1999) Modulation of glioma cell migration and invasion using $\mathrm{Cl}(-)$ and $\mathrm{K}(+)$ ion channel blockers. J Neurosci 19: 5942-5954. [Crossref]

115. Lui VC1, Lung SS, Pu JK, Hung KN, Leung GK (2010) Invasion of human glioma cells is regulated by multiple chloride channels including ClC-3. Anticancer Res 30: 4515-4524. [Crossref]

116. Deshane J, Garner CC, Sontheimer H (2003) Chlorotoxin inhibits glioma cell invasion via matrix metalloproteinase-2. J Biol Chem 278: 4135-4144. [Crossref]

117. Brown PD (1995) Matrix metalloproteinase inhibitors: a novel class of anticancer agents. Adv Enzyme Regul 35: 293-301. [Crossref]

118. Veiseh O, Gunn JW, Kievit FM, Sun C, Fang C, et al. (2009) Inhibition of tumor-cel invasion with chlorotoxin-bound superparamagnetic nanoparticles. Small 5: 256-264. [Crossref]

119. Dardevet L, Rani D, Abd El Aziz T, Bazin I, Sabatier JM, et al. (2015) Chlorotoxin: a helpful natural scorpion peptide to diagnose glioma and fight tumor invasion. Toxins 7: 1079-1101. [Crossref]

120. Mamelak AN, Rosenfeld S, Bucholz R, Raubitschek A, Nabors LB, et al. (2006) Phase I single-dose study of intracavitary-administered iodine-131-TM-601 in adults with recurrent high-grade glioma. J Clin Oncol 24: 3644-3650. [Crossref]

121. Gribbin TE, Senzer N, Raizer JJ, Shen S, Nabors LB, et al. (2009) A phase evaluation of intravenous (IV) 131I-chlorotoxin delivery to solid peripheral and intracranial tumors. J Clin Oncol 27: e14507. [Crossref]
122. Kharrat R, Mansuelle P, Sampieri F, Crest M, Oughideni R, et al. (1997) Maurotoxin a four disulfide bridge toxin from Scorpio maurus venom: purification, structure and action on potassium channels. FEBS Lett 406: 284-290. [Crossref]

123. Abdel-Nabi IM, McVean A, Abdel-Rahman MA, Omran MAA (2004) Intraspecific diversity of morphological characters of the burrowing scorpion Scorpio maurus palmatus (Ehrenberg, 1828) in Egypt (Arachnida: Scorpionida: Scorpionidae). Serket 9: 41-67.

124. Lazarovici P, Yanai P, Pelhate M, Zlotkin E (1982) Insect toxic component from the venom of a chactoid scorpion, Scorpio maurus palmatus (Scorpionidae). J Biol Chem 257: 8397-8404. [Crossref]

125. Lazarovici P, Menashe M, Zlotkin E (1984) Toxicity to crustacea due to polypeptidephospholipase interaction in the venom of a chactoid scorpion. Arch Biochem Biophys 229: 270-286. [Crossref]

126. Ettinger K, Cohen G, Momic T, Lazarovici P (2013) The effects of a chactoid scorpion venom and its purified toxins on rat blood pressure and mast cells histamine release. Toxins 5: 1332-1342. [Crossref]

127. Logsdon NJ, Kang J, Togo JA, Christian EP, Aiyar J (1997) A novel gene, hKCa4, encodes the calcium-activated potassium channel in human T lymphocytes. $J$ Biol Chem 272: 32723-32726. [Crossref]

128. Jensen BS, Strobaek D, Christophersen P, Jorgensen TD, Hansen C, et al. (1998) Characterization of the cloned human intermediate-conductance $\mathrm{Ca} 2+$-activated $\mathrm{K}+$ channel. Am J Physiol 275: C848-856. [Crossref]

129. Castle NA, London DO, Creech C, Fajloun Z, Stocker JW, et al. (2003) Maurotoxin a potent inhibitor of intermediate conductance $\mathrm{Ca} 2+$-activated potassium channels Mol Pharmacol 63: 409-418. [Crossref]

130. Cahalan MD, Wulff H, Chandy KG (2001) Molecular properties and physiological roles of ion channels in the immune system. J Clin Immunol 21: 235-252. [Crossref]

131. Ghanshani S, Wulff H, Miller MJ, Rohm H, Neben A, et al. (2000) Up-regulation of the IKCa1 potassium channel during T-cell activation. Molecular mechanism and functional consequences. J Biol Chem 275: 37137-37149. [Crossref]

132. Jensen BS, Odum N, Jorgensen NK, Christophersen P, Olesen SP (1999) Inhibition of $\mathrm{T}$ cell proliferation by selective block of $\mathrm{Ca}(2+)$-activated $\mathrm{K}(+)$ channels. Proc Natl Acad Sci U S A 96: 10917-10921. [Crossref]

133. Chandy KG, Wulff H, Beeton C, Pennington M, Gutman GA, et al. (2004) K+ channels as targets for specific immunomodulation. Trends Pharmacol Sci 25: 280 289. [Crossref]

134. Shi CM, Liang HB, Altanchimeg D, Nonnaizab, Chuluunjav C, et al. (2015) Climatic niche defines geographical distribution of Mesobuthus eupeus mongolicus (Scorpiones: Buthidae) in Gobi desert. Zoolog Syst 40: 339-348.

135. Sun D, Sun ZN (2011) Notes on the genus Mesobuthus (Scorpiones: Buthidae) in China, with description of a new species. J Arachnol 39: 59-75.

136. Ozkan O, Kat I (2005) Mesobuthus eupeus scorpionism in Sanliurfa region of Turkey. J Venom Anim Toxins incl Trop Dis 11: 479-491.

137. Korolkova YV1, Kozlov SA, Lipkin AV, Pluzhnikov KA, Hadley JK, et al. (2001) An ERG channel inhibitor from the scorpion Buthus eupeus. J Biol Chem 276: 9868 9876. [Crossref]

138. Gao B, Zhu L, Zhu S (2011) A naturally-occurring carboxyl-terminally truncated a-scorpion toxin is a blocker of sodium channels. Biochem Biophys Res Commun 411: 673-678. [Crossref]

139. Gao B, Sherman P, Luo L, Bowie J, Zhu S (2009) Structural and functional characterization of two genetically related meucin peptides highlights evolutionary divergence and convergence in antimicrobial peptides. FASEB J 23: 1230-1245. [Crossref]

140. Yount NY, Yeaman MR (2012) Emerging themes and therapeutic prospects for antiinfective peptides. Annu Rev Pharmacol Toxicol 52: 337-360. [Crossref]

141. Tarazi S (2015) Scorpion venom as antimicrobial peptides (AMPs): a review article. Int Arab J Antimicrob Agents 3: 5.

142. Shai Y (1999) Mechanism of the binding, insertion and destabilization of phospholipid bilayer membranes by alpha-helical antimicrobial and cell non-selective membranelytic peptides. Biochim Biophys Acta 1462: 55-70. [Crossref]

143. Yeaman MR, Yount NY (2003) Mechanisms of antimicrobial peptide action and resistance. Pharmacol Rev 55: 27-55. [Crossref] 
Mans DRA (2017) Exploring the global animal biodiversity in the search for new drugs - Spiders, scorpions, horseshoe crabs, sea spiders, centipedes, and millipedes

144. Harrison PL, Abdel-Rahman MA, Miller K, Strong PN (2014) Antimicrobial peptides from scorpion venoms. Toxicon 88: 115-137. [Crossref]

145. Sherman IW, Prudhomme J, Tait JF (1997) Altered membrane phospholipid asymmetry in Plasmodium falciparum-infected erythrocytes. Parasitol Today 13: 242-243. [Crossref]

146. Gelhaus C, Jacobs T, Andra J, Leippe M (2008) The antimicrobial peptide NK-2, the core region of mammalian NK-lysin, kills intraerythrocytic Plasmodium falciparum. Antimicrob Agents Chemother 52: 1713-1720. [Crossref]

147. Kaushik NK, Sharma J, Sahal D (2012) Anti-plasmodial action of de novo-designed, cationic, lysine-branched, amphipathic, helical peptides. Malar J 11: 256. [Crossref]

148. Walls EA, Berkson J, Smith SA (2002) The horseshoe crab, Limulus polyphemus: 200 million years of existence, 100 years of study. Rev Fish Sci 10: 39-73.

149. Kin A, Błażejowski B (2014) The horseshoe crab of the genus Limulus: living fossil or stabilomorph? PLoS One 9: e108036. [Crossref]

150. Kumar V, Roy S, Sahoo AK, Behera BK, Sharma AP (2015) Horseshoe crab and its medicinal values. Int J Curr Microbiol App Sci 4: 956-964.

151. Liu JS, Passaglia CL (2009) Using the horseshoe crab, Limulus Polyphemus, in vision research. J Vis Exp 29: 1384. [Crossref]

152. Kumar V, Roy S, Sahoo AK, Kumar V (2016) Horseshoe crabs: biomedical importance and its potential use in developing health-care products. Indian J Geo Marine Sci 45: 1234-1244.

153. Levin J, Bang FB (1964) The role of endotoxin in the extracellular coagulation of limulus blood. Bull Johns Hopkins Hosp 115: 265-274. [Crossref]

154. Novitsky TJ (1984) Discovery to commercialization: the blood of the horseshoe crab. Oceanus 27: 13-18.

155. Walls EA, Berkson J (2003) Effects of blood extraction on horseshoe crabs (Limulus polyphemus). Fish Bull 101: 457-459.

156. Kurz W, James-Pirri MJ (2002) The impact of biomedical bleeding on horseshoe crab, Limulus polyphemus, movement patterns on Cape Cod, Massachusetts. Mar Freshwater Behav Physiol 35: 261-268.

157. Fennrich S, Hennig U, Toliashvili L, Schlensak C, Wendel HP, et al. (2016) More than 70 years of pyrogen detection: current state and future perspectives. Altern Lab Anim 44: 239-253. [Crossref]

158. Kawabata S, Muta T (2010) Sadaaki Iwanaga: discovery of the lipopolysaccharideand beta-1,3-D-glucan-mediated proteolytic cascade and unique proteins in invertebrate immunity. J Biochem 147: 611-618. [Crossref]

159. Mizumura H, Ogura N, Aketagawa J, Aizawa M, Kobayashi Y, et al. (2017) Genetic engineering approach to develop next-generation reagents for endotoxin quantification. Innate Immun 23: 136-146. [Crossref]

160. Nakamura T, Furunaka H, Miyata T, Tokunaga F, Muta T, et al. (1988) Tachyplesin, a class of antimicrobial peptide from the hemocytes of the horseshoe crab (Tachypleus tridentatus). Isolation and chemical structure. J Biol Chem 263: 16709-16713. [Crossref]

161. Miyata T, Tokunaga F, Yoneya T, Yoshikawa K, Iwanaga S, et al. (1989) Antimicrobial peptides, isolated from horseshoe crab hemocytes, tachyplesin II, and polyphemusins I and II: chemical structures and biological activity. J Biochem 106: 663-668. [Crossref]

162. Muta T, Fujimoto T, Nakajima H, Iwanaga S (1990) Tachyplesins isolated from hemocytes of Southeast Asian horseshoe crabs (Carcinoscorpius rotundicauda and Tachypleus gigas): identification of a new tachyplesin, tachyplesin III, and a processing intermediate of its precursor. J Biochem 108: 261-266. [Crossref]

163. Chen Y, Xu X, Hong S, Chen J, Liu N, et al. (2001) RGD-Tachyplesin inhibits tumor growth. Cancer Res 61: 2434-2438. [Crossref]

164. Shigenaga T, Muta T, Toh Y, Tokunaga F, Iwanaga S (1990) Antimicrobial tachyplesin peptide precursor. cDNA cloning and cellular localization in the horseshoe crab (Tachypleus tridentatus). Biol Chem 265: 21350-21354. [Crossref]

165. Masuda K, Ohta M, Ito M, Ohsuka S, Kaneda T, et al. (1994) Bactericidal action of tachyplesin I against oral streptococci. Oral Microbiol Immunol 9: 77-80. [Crossref]

166. Kushibiki T, Kamiya M, Aizawa T, Kumaki Y, Kikukawa T, et al. (2014) Interaction between tachyplesin I, an antimicrobial peptide derived from horseshoe crab, and lipopolysaccharide. Biochim Biophys Acta 1844: 527-534. [Crossref]

167. Hong J, Guan W, Jin G, Zhao H, Jiang X, et al. (2015) Mechanism of tachyplesin $\mathrm{I}$ injury to bacterial membranes and intracellular enzymes, determined by laser confocal scanning microscopy and flow cytometry. Microbiol Res 170: 69-77. [Crossref]
168. Cirioni O, Giacometti A, Kamysz W, Silvestri C, Riva A, et al. (2007) In vitro activities of tachyplesin III against Pseudomonas aeruginosa. Peptides 28: 747-751. [Crossref]

169. Lee LF, Mariappan V, Vellasamy KM, Lee VS, Vadivelu J (2016) Antimicrobia activity of Tachyplesin 1 against Burkholderia pseudomallei: an in vitro and in silico approach. Peer J 4: e2468. [Crossref]

170. Xie H, Wei J, Qin Q (2016) Antiviral function of Tachyplesin I against iridovirus and nodavirus. Fish Shellfish Immunol 58: 96-102. [Crossref]

171. Löfgren SE, Miletti LC, Steindel M, Bachère E, Barracco MA (2008) Trypanocida and leishmanicidal activities of different antimicrobial peptides (AMPs) isolated from aquatic animals. Exp Parasitol 118: 197-202. [Crossref]

172. Ding H, Jin G, Zhang L, Dai J, Dang J, et al. (2015) Effects of tachyplesin I on human U251 glioma stem cells. Mol Med Rep 11: 2953-2958. [Crossref]

173. Arango CP, Wheeler WC (2007) Phylogeny of the sea spiders (Arthropoda, Pycnogonida) based on direct optimization of six loci and morphology. Cladistics 23: 255-293.

174. Arnaud F, Bamber RN (1987) The biology of Pycnogonida. Adv Mar Biol 24: 1-95.

175. Arango CP (2002) Morphological phylogenetics of the sea spiders (Arthropoda: Pycnogonida). Org Divers Evol 2: 107-125.

176. Cano E, López-González PJ (2007) Colossendeis species (Pycnogonida: Colossendeidae) collected during the Italica XIX cruise to Victoria Land (Antarctica), with remarks on some taxonomic characters of the ovigers. Scientia Marina 71: 661-681.

177. Soler-Membrives A, Arango CP, Cuadrado M, Munilla T (2013) Feeding biology of carnivore and detritivore Mediterranean pycnogonids. J Mar Biol Assoc UK 93 $635-643$.

178. Bhatia S, Garg A, Sharma K, Kumar S, Sharma A, et al. (2011) Mycosporine and mycosporine-like amino acids: a paramount tool against ultra violet irradiation. Pharmacogn Rev 5: 138-146. [Crossref]

179. Singh SP, Kumari S, Rastogi RP, Singh KL, Sinha RP (2008) Mycosporine-like amino acids (MAAs): chemical structure, biosynthesis and significance as UVabsorbing/screening compounds. Indian J Exp Biol 46: 7-17. [Crossref]

180. Oren A, Gunde-Cimerman N (2007) Mycosporines and mycosporine-like amino acids: UV protectants or multipurpose secondary metabolites? FEMS Microbiol Lett 269: 1-10. [Crossref]

181. Sinha RP, Singh SP, Hader DP (2007) Database on mycosporines and mycosporinelike amino acids (MAAs) in fungi, cyanobacteria, macroalgae, phytoplankton and animals. J Photochem Photobiol Biol 89: 29-35. [Crossref]

182. Karentz D, McEuen FS, Land MC, Dunlap WC (1991) Survey of mycosporine-like amino acid compounds in Antarctic marine organisms: potential protection from ultraviolet exposure. Mar Biol 108: 157-166.

183. Brewer MS, Sierwald P, Bond JE (2012) Millipede taxonomy after 250 years: classification and taxonomic practices in a mega-diverse but understudied arthropod group. PLOS ONE 7: e37240. [Crossref]

184. Sombke A, Edgecombe GD (2014) Morphology and evolution of Myriapoda Arthropod Struct Dev 43: 3-4. [Crossref]

185. Bachvarova D, Doychinov, Deltchev Ch, Stoev P (2015) Habitat distribution of myriapods (Chilopoda, Diplopoda) in the town of Shumen and the Shumen Plateau (NE Bulgaria). Arthropoda Selecta 24: 169-184.

186. Scheller U (2008) A reclassification of the Pauropoda (Myriapoda). Int J Myriap 1: $1-38$

187. Marek PE, Shear WA, Bond JE (2012) A redescription of the leggiest animal, the millipede Illacme plenipes, with notes on its natural history and biogeography (Diplopoda, Siphonophorida, Siphonorhinidae). Zookeys : 77-112. [Crossref]

188. Martino RL, Greb SF (2009) Walking trails of the giant terrestrial arthropod Arthropleura from the upper Carboniferous of Kentucky. J Paleontol 83: 140-146.

189. Regiera JC, Wilson HM, Shultz JW (2005) Phylogenetic analysis of Myriapoda using three nuclear protein-coding genes. Mol Phylogenet Evol 34: 147-158. [Crossref]

190. Edgecombe GD, Giribet G (2007) Evolutionary biology of centipedes (Myriapoda: Chilopoda). Annu Rev Entomol 52: 151-170. [Crossref]

191. Foddai D, Bonato L, Pereira LA, Minelli A (2003) Phylogeny and systematics of the Arrupinae (Chilopoda, Geophilomorpha, Mecistocephalidae) with the description of a new dwarfed species. $J$ Nat Hist 37:1247-1267. 
192. Shelley RM, Kiser SB (2000) Neotype designation and a diagnostic account for the centipede Scolopendra gigantean L. 1758, with an account of S. galapagoensis Bollman 1889 (Chilopoda: Scolopendromorpha: Scolopendridae). Trop Zool 13: 159-170.

193. Bonato L, Edgecombe GD, Lewis JG, Minelli A, Pereira LA, et al. (2010) A common terminology for the external anatomy of centipedes (Chilopoda). Zookeys : 17-51. [Crossref]

194. Hakim MdA, Yang S, Lai R (2015) Centipede venoms and their components: resources for potential therapeutic applications. Toxins 7: 4832-4851. [Crossref]

195. Undheim EA, Fry BG, King GF (2015) Centipede venom: recent discoveries and current state of knowledge. Toxins (Basel) 7: 679-704. [Crossref]

196. Jarrar BM (2010) Morphology, histology and histochemistry of the venom apparatus of the centipede, Scolopendra valida (Chilopoda, Scolopendridae). Int J Morphol 28: $19-25$.

197. Balit CR, Harvey MS, Waldock JM, Isbister GK (2004) Prospective study of centipede bites in Australia. J Toxicol Clin Toxicol 42: 41-48. [Crossref]

198. Veraldi S, Cuka E, Gaiani F (2014) Scolopendra bites: a report of two cases and review of the literature. Int J Dermatol 53: 869-872. [Crossref]

199. Knysak I, Martins R, Bertim CR (1998) Epidemiological aspects of centipede (Scolopendromorphae: Chilopoda) bites registered in Greater S. Paulo, SP, Brazil. Rev Saúde Pública 32: 514-518. [Crossref]

200. Yildiz A, Biçeroglu S, Yakut N, Bilir C, Akdemir R, et al. (2006) Acute myocardial infarction in a young man caused by centipede sting. Emerg Med J 23: e30. [Crossref]

201. Supakthanasiri P, Ruxrungtham K, Klaewsongkram J, Chantaphakul H (2004) Anaphylaxis to centipede bite. J Allergy Clin Immunol 113: S244.

202. Pemberton RW (1999) Insects and other arthropods used as drugs in Korean traditional medicine. J Ethnopharmacol 65: 207-216. [Crossref]

203. Yang S, Liu Z, Xiao Y, Li Y, Rong M, et al. (2012) Chemical punch packed in venoms makes centipedes excellent predators. Mol Cell Proteomics 11: 640-650. [Crossref]

204. Chen M, Li J, Zhang F, Liu Z (2014) Isolation and characterization of SsmTx-I, a specific Kv2.1 blocker from the venom of the centipede Scolopendra subspinipes mutilans L. Koch. J Pept Sci 20: 159-164.

205. Yang S, Yang F, Wei N, Hong J, Li B, et al. (2015) A pain-inducing centipede toxin targets the heat activation machinery of nociceptor TRPV1. Nat Commun 6: 8297. [Crossref]

206. Liu ZC, Zhang R, Zhao F, Chen ZM, Liu HW, et al. (2012) Venomic and transcriptomic analysis of centipede Scolopendra subspinipes dehaani. J Proteome Res 11: 6197-6212. [Crossref]

207. Yang S, Xiao Y, Kang D, Liu J, Li Y, et al. (2013) Discovery of a selective NaV1.7 inhibitor from centipede venom with analgesic efficacy exceeding morphine in rodent pain models. Proc Natl Acad Sci U S A 110: 17534-17539. [Crossref]

208. Misonou H, Mohapatra DP, Trimmer JS (2005) Kv2.1: a voltage-gated $\mathrm{K}+$ channel critical to dynamic control of neuronal excitability. Neurotoxicology 26: 743-752. [Crossref]

209. Skov MJ, Beck JC, de Kater AW, Shopp GM (2007) Nonclinical safety of ziconotide: an intrathecal analgesic of a new pharmaceutical class. Int J Toxicol 26: 411-421. [Crossref]

210. Peng K, Kong Y, Zhai L, Wu X, Jia P, et al. (2010) Two novel antimicrobial peptides from centipede venoms. Toxicon 55: 274-279. [Crossref]

211. Choi H, Hwang JS, Lee DG (2013) Antifungal effect and pore-forming action of lactoferricin B like peptide derived from centipede Scolopendra subspinipes mutilans. Biochim Biophys Acta 1828: 2745-2750. [Crossref]

212. Joon Ha L, In-Woo K, Sang-Hee K, Eun-Young Y, Sung-Hee N, et al. (2013) Biological activities of the synthetic peptide Scolopendrasin I from the centipede, Scolopendra subspinipes mutilans. Kor Soc App Entomol 10: 303.

213. Kwon YN, Lee JH, Kim IW, Kim SH, Yun EY, et al. (2013) Antimicrobial activity of the synthetic peptide scolopendrasin II from the centipede Scolopendra subspinipes mutilans. J Microbiol Biotechnol 23: 1381-1385. [Crossref]

214. Choi H, Hwang JS, Lee DG (2014) Identification of a novel antimicrobial peptide, scolopendin 1, derived from centipede Scolopendra subspinipes mutilans and its antifungal mechanism. Insect Mol Biol 23: 788-799. [Crossref]
215. Lee JH, In-Woo K, Mi-Ae K, Eun-Young Y, Sung-Hee N, et al. (2015) Scolopendrasin I: a novel antimicrobial peptide isolated from the centipede Scolopendra subspinipes mutilans. Int J Indust Entomol 31: 14-19.

216. Lee JH, Kim IW, Kim MA, Ahn MY, Yun EY, et al. (2016) Antimicrobial activity of the scolopendrasin $\mathrm{V}$ peptide identified from the centipede, Scolopendra subspinipes mutilans. J Microbiol Biotechnol [Crossref]

217. Lee H, Hwang JS, Lee DG (2017) Scolopendin, an antimicrobial peptide from centipede, attenuates mitochondrial functions and triggers apoptosis in Candida albicans. Biochem J 474: 635-645. [Crossref]

218. Lee W, Hwang JS, Lee DG (2015) A novel antimicrobial peptide, scolopendin, from Scolopendra subspinipes mutilans and its microbicidal mechanism. Biochimie 118 : 176-184. [Crossref]

219. Lee H, Hwang JS, Lee J, Kim JI, Lee DG, et al. (2015) Scolopendin 2, a cationic antimicrobial peptide from centipede, and its membrane-active mechanism. Biochim Biophys Acta 1848: 634-642. [Crossref]

220. Hou H, Yan W, Du K, Ye Y, Cao Q, et al. (2013) Construction and expression of an antimicrobial peptide scolopin 1 from the centipede venoms of Scolopendra subspinipes mutilans in Escherichia coli using SUMO fusion partner. Protein Expr Purif 92: 230-234. [Crossref]

221. Chaparro E, da Silva Jr PI (2015) Lacrain: the first antimicrobial peptide from the body extract of the Brazilian centipede Scolopendra viridicornis. Int J Antimicrob Agents 48: 277-285. [Crossref]

222. Ma W, Liu R, Qi J, Zhang Y (2014) Extracts of centipede Scolopendra subspinipes mutilans induce cell cycle arrest and apoptosis in A375 human melanoma cells. Oncol Lett 8: 414-420. [Crossref]

223. Ma W, Zhang D, Zheng L, Zhan Y, Zhang Y (2015) Potential roles of Centipede Scolopendra extracts as a strategy against EGFR-dependent cancers. Am J Transl Res 7: 39-52. [Crossref]

224. Zhou YQ, Han L, Liu ZQ, Du KC, Li KY (2011) Effect of centipede extract on cervical tumor of mice and its mechanism. Zhong Yao Cai 34: 859-864. [Crossref]

225. Lee JH, Kim IW, Kim SH, Kim MA, Yun EY, et al. (2015) Anticancer activity of the antimicrobial peptide scolopendrasin VII derived from the centipede, Scolopendra subspinipes mutilans. J Microbiol Biotechnol 25: 1275-1280. [Crossref]

226. Moon SS, Cho N, Shin J, Seo Y, Lee CO, et al. (1996) Jineol, a cytotoxic alkaloid from the centipede Scolopendra subspinipes. J Nat Prod 59: 777-779.

227. Brewer MS, Sierwald P, Bond JE (2012) Millipede taxonomy after 250 years: classification and taxonomic practices in a mega-diverse yet understudied arthropod group. PLOS ONE 7: e37240. [Crossref]

228. Golovatch SI, Kime RD (2009) Millipede (Diplopoda) distributions: a review. Soil Org 81: 565-597.

229. Kime RD, Golovatch SI (2000) Trends in the ecological strategies and evolution of millipedes (Diplopoda). Biol J Linnean Soc 69: 333-349.

230. Snyder BA, Boots B, Hendrix PF (2009) Competition between invasive earthworms (Amynthas cortices, Megascolecidae) and native North American millipedes (Pseudopolydesmus erasus, Polydesmidae): effects on carbon cycle and soil structure. Soil Biol Biochem 41: 1442-1449. [Crossref]

231. Mori K, Takagi Y (2000) Enantioselective synthesis of polyzonimine and nitropolyzonimine, spirocyclic compounds from the defensive glands of a millipede, Polyzonium rosalbum. Tetrahedron Lett 41: 6623-6625.

232. Shear WA, Jones TH, Wesener T (2011) Glomerin and homoglomerin from the North American pill millipede Onomeris sinuata (Loomis, 1943) (Diplopoda, Pentazonia, Glomeridae). Int J Myriap 4: 1-10.

233. Shear WA, McPherson IS, Jones TH, Loria SF, Zigler KS (2010) Chemical defense of a troglobiont millipede, Tetracion jonesi Hoffman (Diplopoda, Callipodida, Abacionidae). Int J Myriap 3: 153-158.

234. Vujisić LV, Makarov SE, Curčić BP, Ilić BS, Tešević VV, et al. (2011) Composition of the defensive secretion in three species of European millipedes. J Chem Ecol 37 1358-1364. [Crossref]

235. Bodner M, Raspotnig G (2012) Millipedes that smell like bugs: (E)-alkenals in the defensive secretion of the julid diplopod Allajulus dicentrus. J Chem Ecol 38: 547 556. [Crossref]

236. Deml R, Huth A (2000) Benzoquinones and hydroquinones in defensive secretions of tropical millipedes. Naturwissenschaften 87: 80-82. [Crossref] 
237. Wu X, Buden D, Attygalle A (2007) Hydroquinones from defensive secretion of a giant Pacific millipede, Acladocricus setigerus (Diplopoda: Spirobolida). Chemoecology 17: 131-138.

238. Hamel J (2011) A review of acute cyanide poisoning with a treatment update. Crit Care Nurse 31: 72-81. [Crossref]

239. Saporito RA, Donnelly MA, Hoffman RL, Garraffo HM, Daly JW (2003) A siphonotid millipede (Rhinotus) as the source of spiropyrrolizidine oximes of dendrobatid frogs. J Chem Ecol 29: 2781-2786. [Crossref]

240. Bodner M, Vagalinski B, Makarov SE, Antic DŽ, Vujisi LV et al. (2016) "Quinone millipedes" reconsidered: evidence for a mosaic-like taxonomic distribution of phenol-based secretions across the Julidae. J Chem Ecol 42: 249-258. [Crossref]

241. De Capitani EM, Vieira RJ, Bucaretchi F, Fernandes LCR, Toledo AS, et al. (2011) Human accidents involving Rhinocricus spp., a common millipede genus observed in urban areas of Brazil. Clin Toxicol (Phila) 49: 187-190. [Crossref]

242. Zito M, Evans S, Weldon PJ (2003) Owl monkeys (Aotus spp.) self-anoint with plants and millipedes. Folia Primatol (Basel) 74: 159-161. [Crossref]

243. Parkes K, Weldon P, Hoffman R (2003) Polydesmidan millipede used in selfanointing by a strong-billed woodcreeper (Xiphocolaptes promeropirhyncus) from Belize. Ornitol Neotrop 14: 285-286.

244. Roncadori R, Duffey S, Blum M (1985) Antifungal activity of defensive secretions of certain millipedes. Mycologia 77: 185-191.

245. Williams LA, Singh PD, Caleb-Williams LS (1997) Biology and biological action of the defensive secretion from a Jamaican millipede. Naturwissenschaften 84: 143144. [Crossref]

246. Kuwahara Y, Omura H, Tanabe T (2002) 2-Nitroethenylbenzenes as natural products in millipede defense secretions. Naturwissenschaften 89: 308-310. [Crossref]

247. Billah MK, Kwang D, Adofo C, Olutaiwo MA, Pesewu GA (2015) Antibacterial activities of millipede extracts against selected bacterial pathogens. J Microbio Antimicrob Agents 1: 30-35.

248. Shear WA (2015) The chemical defenses of millipedes (diplopoda): biochemistry, physiology and ecology. Biochem Syst Ecol 61: 78-117.

249. Stankovic S, Dimkic I, Vujisic L, Pavkovic-Lucic S, Jovanovic Z, et al. (2016) Chemical defence in a millipede: evaluation and characterization of antimicrobia activity of the defensive secretion from Pachyiulus hungaricus (Karsch, 1881) (Diplopoda, Julida, Julidae). PLOS ONE 11: e0167249.

250. Hatzimouratidis K1 (2007) Epidemiology of male sexual dysfunction. Am J Mens Health 1: 103-125. [Crossref]
251. Ramos-Casals M, Brito-Zerón P, Kostov B, Sisó-Almirall A, Bosch X, et al. (2015) Google-driven search for big data in autoimmune geoepidemiology: analysis of 394,827 patients with systemic autoimmune diseases. Autoimmun Rev 14: 670-679. [Crossref]

252. Torre LA, Bray F, Siegel RL, Ferlay J, Lortet-Tieulent J, et al. (2015) Global cancer statistics, 2012. CA Cancer J Clin 65: 87-108. [Crossref]

253. Zaman SB, Hussain MA, Nye R, Mehta V, Mamun KT, et al. (2017) A review on antibiotic resistance: alarm bells are ringing. Cureus 9: e1403. [Crossref]

254. Genetu Bayih A, Debnath A, Mitre E, Huston CD, et al. (2017) Susceptibility testing of medically important parasites. Clin Microbiol Rev 30: 647-669. [Crossref]

255. Bradding P, Wulff $\mathrm{H}(2009)$ The $\mathrm{K}+$ channels $\mathrm{K}(\mathrm{Ca}) 3.1$ and $\mathrm{K}(\mathrm{v}) 1.3$ as novel targets for asthma therapy. Br J Pharmacol 157: 1330-1339. [Crossref]

256. Heinen TE1, da Veiga AB (2011) Arthropod venoms and cancer. Toxicon 57: 497 511. [Crossref]

257. Gati CDC, Mortari MR, Schwartz EF (2012) Towards therapeutic applications of arthropod venom $\mathrm{K}+$-channel blockers in CNS neurologic diseases involving memory acquisition and storage. $J$ Toxicol 2012: 756358. [Crossref]

258. Bordon KCF, Wiezel GA, Amorim FG, Arantes EC (2015) Arthropod venom hyaluronidases: biochemical properties and potential applications in medicine and biotechnology. J Venom Anim Toxins Incl Trop Dis 21: 43. [Crossref]

259. Monge-Fuentes V, Gomes FMM, Campos GAA, Silva JC, Biolchi AM, et al (2015) Neuroactive compounds obtained from arthropod venoms as new therapeutic platforms for the treatment of neurological disorders. J Venom Anim Toxins Incl Trop Dis 21: 31. [Crossref]

260. Sarfo-Poku C, Eshun O, Lee KH (2016) Medical application of scorpion venom to breast cancer: A mini-review. Toxicon 122: 109-112. [Crossref]

261. Windley MJ, Herzig V, Dziemborowicz SA, Hardy MC, King GF, et al. (2012) Spider-venom peptides as bioinsecticides. Toxins (Basel) 4: 191-227. [Crossref]

262. Koenemann S, Schram FR, Iliffe TM, Hinderstein LM, Bloechl A (2007) Behavio of Remipedia in the laboratory, with supporting field observations. J Crust Biol 27: 534-542.

263. Pineda SS, Undheim EA, Rupasinghe DB, Ikonomopoulou MP, King GF (2014) Spider venomics: implications for drug discovery. Future Med Chem 6: 1699-1714. [Crossref]

264. Carmo AO, Chatzaki M, Horta CC, Magalhães BF, Oliveira-Mendes BB5, et al (2015) Evolution of alternative methodologies of scorpion antivenoms production. Toxicon 97: 64-74. [Crossref]

Copyright: (C2017 Mans DRA. This is an open-access article distributed under the terms of the Creative Commons Attribution License, which permits unrestricted use, distribution, and reproduction in any medium, provided the original author and source are credited. 